\title{
EL FLETAMENTO DE MERCANCÍAS EN LA CARRERA DE INDIAS (1560-1622): INTRODUCCIÓN A SU ESTUDIO
}

\author{
SERGIO M. RODRÍGUEZ LORENZO*
}

\begin{abstract}
Resumen: La carrera de Indias constituye el sistema marítimo-mercantil que comunica a España con sus colonias americanas. Toda Europa participa en esa ruta bajo jurisdicción de la Monarquía Católica. Hasta México, Perú o el Caribe se llevan mercancías que se venden por plata y otros productos preciosos. Son muchas las actividades económicas que dan forma a esta ruta marítima; pero la base de todo es el negocio naviero. El contrato que regula las relaciones entre comerciantes y señores de naos es el fletamento. El presente trabajo analiza las diferentes cláusulas de los fletamentos de mercancía y defiende que, a pesar de la intervención de la Corona, la carrera de Indias fue un ámbito de libertad económica, regido por la negociación privada y la espontaneidad institucional propia del derecho marítimo.
\end{abstract}

Palabras clave: Historia económica, negocio naviero, fletamentos, mercantilismo, derecho marítimo.

Clasificación JEL: L260, N010, N730, N830.

Abstract: The carrera de Indias constitutes the maritime-mercantile system that communicates Spain with his American colonies. The whole Europe takes part in this route under the jurisdiction of the Catholic Monarchy. Up to Mexico, Peru or the Carib there arrives many goods that sell for silver and other precious products. There are many economic activities that give form to this maritime route; but the base of everything is the shipping business. The contract that regulates the relations between merchants and masters of the vessels is the freightment. The present work analyzes the different clauses of the freightments of goods and defends that, in spite of Crown's interventions, the carrera de Indias was an area of economic freedom, been ruled by the private negotiation and the institutional spontaneity of the maritime law.

* Centro de Estudios Históricos Tomás de Mercado (Salamanca).

Email: srodriguezlorenzo@gmail.com 
Key words: Economic history, shipping business, freightments, mercantilism, maritime law.

JEL Classification: L260, N010, N730, N830.

\section{I \\ INTRODUCCIÓN}

Según Veitia Linaje, los barcos se fabrican con dos fines: para la lucha en la guerra o para el transporte de mercancías. ${ }^{1}$ Esta última es la actividad esencial del negocio naviero, si bien la naturaleza de la carrera de Indias como ruta marítima provoca que muchos barcos mercantes se dediquen a labores militares, y que bastantes navíos de guerra descuiden su función militar para ocuparse en negocios propios de los buques mercantes. A pesar de estas discordancias, el ingreso que justifica la empresa naviera proviene de la suma que se paga por el transporte de mercancías y personas, cuyas condiciones se establecen a través de los contratos de fletamento.

El contrato de fletamento ya es conocido por los griegos, y su práctica alcanza un auge enorme con el imperio romano. ${ }^{2}$ Cae en desuso durante los siglos de la Alta Edad Media, debido a la generalización de un régimen asociativo en las empresas marítimo-mercantiles que apenas distingue entre la figura del naviero y el mercader, y donde la relación contractual establecida en el fletamento se vuelve innecesaria. ${ }^{3}$ A partir del renacimiento comercial del siglo XII, ${ }^{4}$ se produce en el occidente europeo una diferenciación cada vez más clara entre ambas funciones económicas: transporte y comercio. En el siglo XV, y sobre todo desde el siglo XVI, surge la navegación como empresa autónoma, encargada de transportar las mercancías del mercader. Tras la recuperación de su utilidad, el fletamento se ha considerado - hasta

\footnotetext{
1 Veitia Linaje (1672), lib. I, cap. XVI, 1.

2 Fernández-Guerra Fernández (1991), pp. 15-30.

3 García Sanz (1978), pp. 236-239.

4 Pirenne (1933), pp. 26-35.
} 
hoy- el contrato base del comercio marítimo y, junto a la compraventa, el acto mercantil por excelencia. ${ }^{5}$

Por motivos metodológicos, el análisis de los fletamentos precisa de una división en dos grupos. De un lado, aquellos que conciertan el transporte de mercancías; de otro, los que se refieren al transporte de personas, es decir, los contratos de pasaje. Dentro del primer grupo deben incluirse las cargazones de esclavos, pues en la época tenían la ominosa consideración de mercancía. Aunque hubo fletamentos que en un mismo contrato convinieron tanto la carga de mercaderías como el pasaje de personas, las cláusulas se separaban según el objeto de transporte y permiten un estudio por separado. Este trabajo se dedica exclusivamente a los fletamentos de mercancías, que por su importancia económica formaban el núcleo del negocio naviero y el ingreso fundamental del señor de nao.

Entre los fletamentos de mercancías, quedan ahora de lado los que tocan a esclavos. En primer lugar, porque el transporte de la mayoría de los esclavos a América no precisó de escrituras de fletamento, sino otros tipos de contrato; y en segundo lugar, por la distinta problemática que plantea una mercancía sui generis como la de los esclavos con respecto a otras que se trasiegan en la carrera de Indias.

Se deja también para otra ocasión el estudio de los fletamentos de vuelta, es decir, los contratos de transporte firmados en las Indias con destino a España. La razón es sencilla: parece que no se otorgaron esa clase de escrituras. Las mercancías que se navegan desde América hasta los puertos españoles —al menos en el periodo aquí estudiado- se rigen contractualmente por las «fe de registro" y las simples anotaciones en los libros de sobordo de maestres y dueños de naos. Se desconoce la causa; quizá la escasez de notarios en los puertos indianos y el encarecimiento que supondría acudir al servicio de los disponibles.

Igualmente pospongo para momento más adecuado el estudio de la conflictividad entre los participantes en el negocio de los fletamentos, que puede conocerse bastante bien a través de los pleitos entre partes conservados en el Archivo de Indias.

\footnotetext{
${ }^{5}$ Rubio (1954), p. 3.
} 
Aunque sigo el consejo de Lord Acton - «Estudiad problemas, no periodos» ${ }^{6}$, también hago caso de las enseñanzas de don Antonio Domínguez Ortiz, para quien «la periodización no es un mero recurso pedagógico destinado a facilitar el estudio de una época mediante oportunas subdivisiones [...], sino un método para ahondar en el proceso histórico y descubrir los puntos críticos». ${ }^{7}$ Así, los límites cronológicos de este trabajo - y de mi futura tesis doctoral- enmarcan lo que Chaunu denominó «la seconde phase longe d'expansion» (1559/1562-1592) y «le renversement de la tendance majeure» (1592-1622) en el tráfico de la carrera de Indias. ${ }^{8}$ Estos dos ciclos mayores contienen a su vez numerosos ciclos cortos, hasta el extremo de que cada año presenta peculiaridades y problemas distintos a los demás. En 1560 comienza a superarse «la grande récession intercyclique» de mediados del Quinientos que toca fondo en 1554. ${ }^{9}$ Además de por el incremento del tráfico, la sexta década del siglo XVI posee bastante importancia en la trayectoria de la Carrera por otros motivos. Tras varias vicisitudes, es entre 1561 y 1566 cuando se concreta el sistema oficial castellano de navegación en la ruta trasatlántica característico de la dinastía Habsburgo, en especial a partir de la real provisión de 18 de octubre de 1564, que establece dos flotas anuales e independientes según su destino: a Nueva España en abril (retrasada a mayo en 1582) y a Tierra Firme en agosto. ${ }^{10} \mathrm{~A}$ fines de esta década también tiene lugar el proceso de creación de la Universidad de Mareantes, corporación defensora de los intereses de sus miembros navieros, y se cierra el círculo de instituciones formales de la carrera de Indias, integrado por el Consejo de Indias, la Casa de la Contratación, el Consulado de Sevilla y la propia Universidad de Mareantes. ${ }^{11}$

6 Citado en Collingwood (1946), p. 271.

7 Domínguez Ortiz (1984), p. 29.

8 Chaunu (1955-1960), tomo VIII 2,1 , pp. 355-840, y tomo VIII 2,2 pp. 851.

9 Ibid., tomo VIII 2,1 , pp. 257-352.

10 Haring (1918), pp. 258-261. El tenor completo de la real provisión de 18 de octubre de 1564 en: Encinas (1596), tomo IV, pp. 130-133.

11 La real provisión que aprueba las ordenanzas de la Universidad de Mareantes, fechada en Galapagar el 22 de marzo de 1569, en: Actas de la Universidad de Mareantes (1972), pp. 295-315. 
El año 1622 cierra las dos décadas-bisagra que corren entre 1598 y 1621, el reinado de Felipe III, donde conviven los últimos elementos del periodo de hegemonía en la Monarquía Católica y los primeros síntomas inequívocos de la decadencia política. ${ }^{12}$ En la carrera de Indias, 1622 marca, entre otras cosas, el inicio de la cuesta abajo en el volumen de toneladas medido a través de las estadísticas oficiales, ${ }^{13}$ declive que, tras alcanzar su punto más bajo en la década de 1660, no muestra síntomas de revitalización, siquiera moderados, hasta fines del siglo XVII. ${ }^{14}$

La documentación que nos sirve de asiento es fundamentalmente notarial, en concreto la procedente de los protocolos de Sevilla, cabecera oficial de las flotas de la Carrera entre 1503 y 1680. Los documentos custodiados en el Archivo General de Indias se emplean en este trabajo para un asunto muy concreto: las tasaciones en el precio de los fletes en 1572, así como algunas de las reacciones a que dieron lugar entre los afectados. Se trata, pues, en su mayor parte, de un ensayo analítico de los contratos de fletamentos per se, sin más intermediarios entre nosotros y los documentos que algunos de los principios teóricos de la escuela austriaca, como el individualismo metodológico, la teoría subjetiva del valor, los órdenes espontáneos o la empresarialidad.

El uso que hago de las teorías austriacas no tiene un carácter vindicativo desde un punto de vista moral. Como utillaje hermenéutico, simplemente dan mejor cuenta de «lo que sucedió» en un aspecto concreto de la carrera de Indias. La lucha de clases, la teoría de la explotación, la frontera de posibilidades de producción o el precio de equilibrio no nos permiten decir nada sobre los fletamentos en la carrera de Indias entre 1560 y 1622. Pero tampoco haremos demasiado explícita la teoría austriaca. Será más un ensayo para quien sepa leer, que un como dijo Mises, Hayek o Kirzner.

Por último, dos advertencias, una más importante que otra. Primero: se trata de un estudio que comienza in media res, da por sabida muchas cosas en el lector. No debe preocuparle, todas las

\footnotetext{
12 Vilar (1956), pp. 332-346; Bennassar (1983), p. 333; Elliott (1982), pp. 198-223.

13 Véase Chaunu (1955-60), tomo VIII 2,2 , pp. 1515-1525.

${ }^{14}$ García Fuentes (1979), pp. 251-286; García Fuentes (1980), pp. 209-236.
} 
aclaraciones $a b$ initio serán dadas en la futura tesis doctoral en que debe fraguar este adelanto provisional. Segundo: la muestra documental que sirve de base es exigua; en concreto, 236 escrituras de fletamento. Ya se han localizado y fichado otros 750 contratos; pero lo que sigue se ha escrito a partir del análisis de lo recogido en una primera fase de busca.

\section{II \\ DEFINICIÓN Y NATURALEZA JURÍDICA DEL FLETAMENTO}

Los estudios sobre el fletamento en la Baja Edad Media y en la Edad Moderna se han centrado en sus aspectos jurídicos, desde la perspectiva de dos disciplinas complementarias: el derecho mercantil y la diplomática documental. Los mayores esfuerzos se han dirigido a determinar la naturaleza jurídica del fletamento, aunque hasta el momento no se ha alcanzado una respuesta unívoca y definitiva a este problema. Tradicionalmente, los especialistas del Derecho han defendido dos posturas solo contradictorias en apariencia: una que considera al fletamento como arrendamiento de cosa o locatio rei, y otra que ve en él un contrato de obra o locatio operis, según se otorgue más importancia al medio (buque) o al fin (transporte).

En 1617 sale de la imprenta limeña de Francisco del Canto el Laberinto del Comercio terrestre y naval, obra de Juan de Hevia Bolaños. ${ }^{15}$ Se trató del primer intento de adaptar el Derecho tradicional al estado del comercio y navegación de su época, con particular interés en las relaciones mercantiles entre España y las Indias. En el capítulo 5. ${ }^{\circ}$ del libro III, expone su doctrina del fletamento, de amplia difusión entre los coetáneos. Para Hevia Bolaños,

Fletamento es el contrato que se hace entre el dueño o maestre de la nave, y el que lleva sus cosas en ella para llevarlas de una a otra parte, y por ello pagarle el precio del flete que concertaren,

15 Hevia Bolaños (1617). 
como consta de una ley de Partida que pone la forma del libelo. Y así es un contrato de alquiler, en que el dueño o maestre de la nave la alquila para en ella llevar sus cosas por el precio que por ello le da, como se dice en el Derecho civil y real. ${ }^{16}$

Jesús Rubio considera que la naturaleza jurídica del fletamento obtenida de esta definición es la de un «contrato de transporte de mercaderías por mar», donde la palabra «alquiler» debe interpretarse en un sentido amplio que integre a «todas las especies de "locatio-conductio" ». ${ }^{17}$ De las notas de Hevia Bolaños a su texto se infiere una triple influencia en su concepción del fletamento: el Derecho romano a través del Digesto o las obras de romanistas como Diego de Covarrubias y Antonio Gómez; las ideas mercantilistas italianas, con Benvenuto Straccha como principal representante; y el Derecho peninsular procedente de Las Partidas, la Nueva Recopilación o las ordenanzas de los consulados de Burgos y Sevilla. ${ }^{18}$ Rubio piensa que todas estas fuentes conciben el fletamento como un contrato de transporte, de ahí que la idea pase a Hevia para satisfacer de este modo las necesidades de la navegación de fines del siglo XVI y principios del XVII. ${ }^{19}$

Pero no todos los estudiosos llegan a la misma interpretación. María Milagros del Vas Mingo cree que ni Hevia Bolaños ni sus fuentes conceptúan el fletamento como contrato de transporte, sino como arrendamiento de navío, aunque siempre estuviese implícita la finalidad del mismo (el transporte); hace un uso restrictivo de la acepción que Hevia da a la palabra «alquiler», y asume la etimología de «fletamento» que propone Veitia Linaje, para quien deriva de «aflectamento», pues en una ley de Las Partidas «se llamaba así al arrendamiento de las naos, y de allí quedó flectamento». ${ }^{20}$ Defiende, además, que la estimación del fletamento como alquiler de buque se ajustaba a las condiciones

\footnotetext{
16 Ibid., lib. III, cap. 5.ำ 1 .

17 Rubio (1944), p. 578.

18 Ibid., pp. 575-576.

19 Ibid., p. 576.

20 Veitia Linaje (1672), lib. II, cap. XVI, 1. Vas Mingo (1989), pp. 39-41.
} 
reales del comercio marítimo de la época. Según Vas Mingo, ante los numerosos riesgos de la navegación, varios mercaderes unen sus esfuerzos para contratar un barco en el que viajar con sus mercancías, y donde todo lo relativo al transporte incumbe a los propios comerciantes, mientras que el naviero ocupa un papel secundario en todo el proceso. ${ }^{21}$ Esto justificaría - sin que nos explique la razón-que en los contratos se declarase de manera expresa la nave objeto de fletamento, con su nombre, porte, lugar de surtimiento, etc., o que el naviero estuviese obligado a entregar el barco bien aparejado y con todos sus elementos (casco, árboles, velas y jarcias) en estado de hacer la travesía. ${ }^{22}$

Tanto Rubio como Vas Mingo comparten un defecto en la interpretación de la naturaleza legal del fletamento: sus argumentos no se basan en la práctica efectiva, documental, de los contratos notariales, sino en la doctrina jurídica elaborada a partir de códigos de leyes o el parecer de los comentaristas. Este modo de proceder, siempre arriesgado en materia historiográfica, lo es más cuando se trata de cuestiones de Derecho marítimo, cuya práctica contractual suele distanciarse de los modelos legales establecidos por el Estado. Aun con esta carencia, y sobre la base de los contratos originales consultados, parece que la posición de Jesús Rubio se acerca más a la realidad de la carrera de Indias, es decir, que el fletamento consiste en un contrato de transporte de mercaderías y personas, y no un alquiler de buque.

El arrendamiento de navío debe entenderse como la cesión que el propietario del barco (arrendador) hace a otra persona (arrendatario o inquilino) de la explotación económica de la nave por un tiempo determinado a cambio de una suma concreta de dinero. El arrendatario se convierte de este modo en naviero, y obtiene su ganancia con el transporte de mercancías a terceros a través de sus respectivos contratos de fletamento. Del análisis de las cláusulas de los fletamentos no se desprende que el fletador ${ }^{23}$

21 Vas Mingo (1989), p. 37. Esta idea linda con el anacronismo, pues el régimen comunitario en la empresa de navegación (que no diferencia entre naviero y mercader, y que gestiona la explotación comercial del buque sin necesidad de contratos de fletamento), ya casi ha desaparecido en el siglo XV, como demuestra García Sanz (1978), pp. 236-241.

22 Vas Mingo (1989), «Las cartas de fletamento», p. 40. 
— supuesto arrendatario según la interpretación de Vas Mingoasuma función de naviero, a cuyo cargo corra el armamento y el beneficio económico del buque. Ni siquiera los casos más dudosos, tales como los fletamentos por la nao entera o al través, ${ }^{24}$ caben explicarse como arrendamientos, sino que prefiguran ciertos rasgos del contrato de time-charter actual, en el que el barco pasa a disposición del fletador con el derecho de intervención en todo lo relacionado con el viaje, partidas, embarque y desembarque de las mercancías, pero donde el fletante o naviero se ocupa de los asuntos náuticos, así como del apresto del barco, su reparación, el pago de la tripulación, etc. ${ }^{25}$

Sí encontramos verdaderos arrendamientos de naves cuando la Corona y sus instituciones delegadas adquieren el servicio de buques de propiedad privada para operaciones generalmente militares. Las condiciones de este arrendamiento quedan establecidas en un «asiento» ${ }^{26}$ firmado entre el señor de la nao (o su maestre) y las autoridades representantes del rey. Pero en estos casos de alquiler de buques, por lo común forzosos, no estamos, strictu sensu, ante contratos de fletamento, ni por su forma diplomática ni por las cláusulas específicas que lo componen. ${ }^{27}$

23 Es a partir de 1829 cuando se emplean los términos «fletante» y «fletador» para designar las dos partes de un contrato de fletamento. Fletante es la parte encargada del transporte, es decir, el naviero; mientras que fletador es la parte que realiza la carga, el comerciante o cargador (Rubio (1954) p. 31, n. 44).

24 Rubio afirma que en caso de fletamento de toda la nave estaríamos «indudablemente en presencia de una locatio rei». (Ibid., p. 13).

25 Padilla González (1989).

26 El asiento «era un documento legal contraído no entre el rey y un súbdito, sino entre dos individuos particulares a los que obligaba mutuamente. La relación que establecía era de reciprocidad moral y legal, no de orden y obediencia; era una relación que, desde el punto de vista legal, no podía darse por terminada y enmendarse unilateralmente sin llegar a un acuerdo o seguir el debido proceso, y aunque esto no era siempre una garantía para el asentista, constituía una verdadera inhibición para la libertad de acción del rey.» (Thompson (1981), p. 315).

27 Pedro Fernández-Guerra afirma que entre las formas de contratación utilizadas por la Corona también se cuenta el contrato de "semiobligado fletamento", que se distingue - no indica en qué — del «arrendamiento forzoso efectuado a través del embargo o requisa de la nave, usado cuando el armador se resistía al alquiler mediante asiento", con lo cual mezcla sin orden los conceptos de asiento, arrendamiento, alquiler y fletamento. (Fernández-Guerra Fernández (1993), pp. 59 y 61). 
Este debate sobre la naturaleza jurídica del fletamento es trascendente para la economía marítima actual. La interpretación del ordenamiento legal será distinta según el concepto de fletamento del que se parta, y las diferencias entre fletante y fletador se dirimirán en un sentido u otro atendiendo a este punto de partida. Sin embargo, no sucede lo mismo en la carrera de Indias durante la segunda mitad del siglo XVI y principios del XVII. A pesar de obras como la de Hevia Bolaños, el único argumento válido que se podía esgrimir en los conflictos relativos a fletamentos era la adecuación de los hechos denunciados al tenor exacto de los contratos notariales, los conocimientos de embarque o las fe de registros, sin que las doctrinas jurídicas circulantes tuvieran mucho que decir. En caso de duda no se recurre al peritaje de expertos en Derecho, sino al testimonio de maestres, pilotos, marineros o mercaderes, quienes acuden siempre a la experiencia, a la costumbre, al modo de hacer las cosas en la carrera de Indias, y no a doctrinas emanadas de un modo $u$ otro de la burocracia estatal.

El examen de las cláusulas de los fletamentos ha sido otro de los aspectos de interés para la literatura sobre las instituciones mercantiles. En el marco de la carrera de Indias, destaca la labor de José Martínez Gijón, cuya obra supone el punto de referencia básico para cualquier investigación dedicada al fletamento indiano. ${ }^{28}$ Los estudios posteriores se limitan a repetir sus ideas, incluidas las menos acertadas. ${ }^{29}$ Rasgo común de estos trabajos es la adopción de un punto de vista jurídico-diplomático demasiado estrecho, que poco ayuda a la explicación de la empresa de transporte marítimo y al comportamiento económico de sus actores. De cualquier manera, no está de más advertir que tras la aparente frialdad de las fórmulas notariales, los contratos de fletamento son el reflejo documental fehaciente de las prácticas cotidianas del naviero en su negocio. Lejos de cualquier estereotipo, los fletamentos presentan en su tenor un elevado casuismo, consecuencia de la directa negociación entre las partes implicadas

\footnotetext{
28 Martínez Gijón (1983), pp. 119-156, y Martínez Gijón (1987), pp. 51-74.

${ }_{29}$ Fernández-Guerra (1991), pp. 162-168; Iglesias Rodríguez (1994), pp. 437-458; Rojas Vaca (1996), pp. 72-112.
} 
en el contrato. Por otro lado, la repetición excesiva de determinadas cláusulas no les confiere menos valor que aquellas que se escrituran de vez en cuando. Lo permanente y lo excepcional suponen en ambos casos la adecuación de los intereses entre fletante y fletador en el concierto del viaje atlántico tras un acuerdo verbal sobre los derechos y obligaciones de cada uno. Todas las cláusulas tienen, pues, su razón de ser: el formulismo notarial no está reñido con el carácter pragmático de la actividad marítimo-mercantil.

\section{III \\ ELEMENTOS PERSONALES DEL CONTRATO: FLETANTES Y FLETADORES}

El fletante es el actor principal del fletamento. Representa a la empresa de transporte y puede actuar de modo directo, si se trata del propio señor de nao, o de modo indirecto, mediante la comparecencia del maestre u otros poderhabientes. En la mayoría de los casos, el dueño de la nave actúa como otorgante del contrato. Con frecuencia, a la condición de propietario se añade la de maestre o capitán. Los señores de naos no solo dirigen su empresa de primera mano en tierra, sino que asiduamente navegan en sus barcos. La presencia del señor a bordo contribuye a la celeridad en el despacho del navío, evita con su autoridad algunos de los conflictos entre los tripulantes, disminuye los riesgos de la navegación por el interés en la conservación de un bien propio $y$, en definitiva, incrementa la eficacia económica de la expedición en beneficio particular de la propiedad.

Cuando el naviero no otorga el contrato, quien suele hacerlo es el maestre, verdadero alter ego del señor de nao y entre cuyas atribuciones está el fletamento de la nave a su cargo. No necesita mostrar un poder del dueño, pues se supone que la capacidad de firmar fletamentos es consustancial al maestraje. ${ }^{30}$ Tampoco

30 Archivo Histórico Provincial de Sevilla, Protocolos Notariales (en adelante AHPSPN), leg. 5925, fols. 22v-23r, carta de maestraje de Sancho González, Sevilla, 18 de abril de 1560; AHPSPN, leg. 12381, fols. 356r-358r, carta de maestraje de Pedro 
resulta extraño que señores y maestres suscriban fletamentos de manera mancomunada. ${ }^{31}$

Con el fin de aumentar su capacidad de negociación, los señores de naos extienden poderes entre algunos oficiales de la nave, como el piloto, ${ }^{32}$ el escribano, ${ }^{33}$ el contramaestre, ${ }^{34}$ etc., para que puedan fletarla en Sevilla o en otras plazas como Sanlúcar de Barrameda, Cádiz o Jerez. ${ }^{35}$ También reciben esta clase de poderes personas ajenas a la empresa, si bien siempre inmersas en el mundo de la carrera de Indias, o unidas por cierto parentesco. ${ }^{36}$ Si el naviero se encuentra alejado del lugar donde se piensa contratar la carga para el barco, igualmente recurre a los poderes para que otros busquen fletadores en su ausencia. ${ }^{37}$

Por su parte, el fletador constituye el agente secundario del contrato. Su papel se limita a una cláusula de aceptación de todos los puntos que el fletante ha estipulado con anterioridad. Representa al interesado en las mercancías que han de cargarse en la nave objeto del fletamento. Al igual que el fletante, puede actuar de manera directa, cuando fletador y propietario de la carga

González, Sevilla, 29 de octubre de 1565; AHPSPN, leg. 7762, fols. 548r-551r, carta de maestraje de Alonso Galdames, Sevilla, 12 de julio de 1569; AHPSPN, leg. 7772, fols. 1095r-1098r, carta de maestraje de Martín de Utarte, Sevilla, 26 de julio de 1572, y muchas más. (Los conciertos de maestraje serán objeto de un estudio pormenorizado en el capítulo que mi futura tesis doctoral dedicará a las tripulaciones).

31 Sirva de ejemplo, AHPSPN, leg. 7758, fols. 12r-15r, carta de fletamento de Pedro de la Fuente y Miguel González, Sevilla, 30 de diciembre de 1567.

32 AHPSPN, leg. 7760, fols. 540r-541r, carta de poder de Antón Sánchez de Armas, Sevilla, 13 de noviembre de 1568. AHPSPN, leg. 7772, fols. 316r-317r, carta de poder de Rodrigo González, Sevilla, 14 de mayo de 1572.

33 AHPSPN, leg. 16845, fols. 10v-12r, carta de poder de Fermín de Inurriza, Sevilla, 28 de agosto de 1616; AHPSPN, leg. 14494, fols. 529v-531r, carta de poder de Vicente de Uresti, Sevilla, 4 de mayo de 1619.

34 AHPSPN, leg. 16726, fols. 344v-345v, carta de poder de Juan Griego, Sevilla, 20 de octubre de 1584

35 AHPSPN, leg. 7776, fols. 148v-150r, carta de poder de Jácome de Rodas, Sevi1la, 7 de octubre de 1573 .

36 AHPSPN, leg. 3408, fols. 611r-612v, carta de poder de Cristóbal Romero El Viejo, Sevilla, 27 de febrero de 1561; AHPSPN, leg. 3409, fols. 864r-865v, carta de poder de Leandro Camacho, Sevilla, 22 de marzo de 1561; AHPSPN, leg. 7760, fol. 962r-v, carta de poder de Bernardo de Andino, Sevilla, 11 de enero de 1569.

37 AHPSPN, leg. 7781, fols. 345r-346r, copia de poder de Gaspar de Cerralta, Veracruz (México), 10 de abril de 1574. 
coinciden en la misma persona, o indirectamente, merced a un poder extendido por el dueño de las mercaderías a un tercero. ${ }^{38}$ Los miembros de una compañía comercial comparecen en ocasiones de mancomún. ${ }^{39}$ También se da el caso de contratos en los que los fletadores son más de uno, pero la carga y las responsabilidades inherentes al fletamento se establecen por separado. ${ }^{40}$

Mientras que el naviero o sus delegados siempre están presentes ante el escribano público en el momento de redacción de la carta notarial, no ocurre lo mismo con el cargador. Son muchos los ejemplos en los que el fletador está «ausente». Este hecho en apariencia nimio denota un acuerdo verbal de las partes en el negocio (actio) que luego se escritura (conscriptio). No es difícil imaginar la situación. En las Gradas o sus alrededores, en cualquier taberna o en la morada del fletador o del fletante, se inician las conversaciones que desembocan en el contrato de fletamento. La capacidad de negociación se prueba entonces. Tras el tira y afloja, si se llega al término en que ambas partes quedan satisfechas, solo resta poner por escrito lo convenido. Cuando el fletador acompaña al fletante hasta el notario, el regateo en las condiciones se lleva hasta las mismas puertas del oficio de escribano; pero muchos quehaceres ocupan al fletador y por eso no es extraño que el fletante acuda solo a realizar el contrato. Más tarde, otro día, quizá aprovechando la visita al escribano para otros asuntos, el cargador lee las cláusulas del fletamento, examina su correspondencias con las obligaciones pactadas y garabatea su firma en la escritura matriz, junto a la del naviero. Que esto es así y que a veces los acuerdos se frustran, queda bien claro en esas escrituras interrumpidas en cualquier fase de su otorgamiento y que el escribano da por zanjada con el lacónico «no pasó».

38 AHPSPN, leg. 5947, fols. 80r-81r, carta de poder de Pedro de Sepúlveda, Sevilla, 8 de enero de 1565 .

39 AHPSPN, leg. 5926, fol. 372r-v, carta de fletamento de Juan Márquez, Sevilla, 9 de septiembre de 1560; AHPSPN, leg. 12380, fol. 935r-v, carta de fletamento de Francisco de Morales, Sevilla, 21 de marzo de 1565; AHPSPN, leg. 5947, fols. 473r-474v, carta de fletamento de Ruy Díaz Matamoros, Sevilla, 7 de abril de 1565.

40 AHPSPN, leg. 7771, fols. 795r-796v, carta de fletamento de Sebastián de Flores, Sevilla, 4 de febrero de 1572. 
La descripción de estas escenas, imaginadas aunque verosímiles, redundan en la idea de historia que defiende la escuela austriaca: los hombres y sus relaciones personales configuran el eje de toda negociación, de todo comportamiento económico; el hombre es la propia medida del hombre, y los gráficos, coyunturas, cifras y estructuras o vienen a demostrarlo o no nos sirven para nada.

\section{IV}

\section{ELEMENTOS REALES DEL CONTRATO: NAVES, CARGAZONES Y FLETES}

La nave es el tercer elemento del contrato. Aparece individualizada por su nombre, el lugar de surtimiento, el destino de su viaje con especificación de las posibles escalas y el modo de navegación (si sola o en compañía de alguna flota o armada). El fletante está obligado a ofrecer una nao en buenas condiciones y con la tripulación suficiente de acuerdo con las exigencias del viaje. Esta cláusula de navegabilidad, salvo rarísima excepción, ${ }^{41}$ aparece en todos los contratos y su tenor es bastante uniforme:

Y me obligo de le dar y entregar la dicha mi nao estanca de quilla y costado y bien aparejada, marinada y artillada de todo lo necesario, según conviene a nao que semejante viaje ha de hacer. ${ }^{42}$

Martínez Gijón indica que la aceptación de esta cláusula por parte del fletador libera de responsabilidad al fletante en caso de que la carga sufra daños a consecuencia del mal estado de la nao, el cual ha de entenderse como caso fortuito, pues el fletante habría cumplido con su compromiso de la entrega de la nave en condiciones de navegar. ${ }^{43}$ Esta interpretación de la cláusula

41 AHPSPN, leg. 5947, foliación rota, carta de fletamento de Álvaro de Columbres, Sevilla, 8 de enero de 1565; AHPSPN, leg. 7760, fols. 75r-76r, carta de fletamento de Bernardo de Andino, Sevilla, 8 de octubre de 1568.

42 Este tenor concreto está tomado de AHPSPN, leg. 16836, fols. 913r-195r, carta de fletamento de Lucas Urquiaga, Sevilla, 7 de febrero de 1615.

43 Martínez Gijón (1983), p. 125. 
de navegabilidad es errónea. Cuando se otorga el contrato de fletamento, la nave objeto de él suele encontrarse en la fase de apresto, reparación y enrole de tripulantes, es decir, no cumple las condiciones que establece la cláusula de navegabilidad, que debe considerarse como obligación del fletante para el futuro, ya sea en el momento de embarque de la carga o al darse a la vela. Por consiguiente, los daños causados en la carga por un posible mal estado de la nave podían ser causa de denuncia y pleito entre fletante y fletador, como de hecho ocurrió más de una vez.

En una ocasión encontramos que esta cláusula de navegabilidad se hace más concreta y que el fletante se puede obligar incluso a artillar su nao con un número determinado de piezas de artillería: Alonso Martín, vecino de Huelva y maestre de la nao San Gabriel, se compromete a llevar en la dicha nave «cuatro tiros de bronce buenos», según consta en el fletamento que concierta con Francisco del Río. ${ }^{4}$

Sobre la cláusula de navegabilidad sigue corriendo tinta hasta nuestros días. La Universidad de Chile en Santiago, por ejemplo, celebró el 9 de septiembre de 2010 un Seminario de Derecho Marítimo en el que Eugenio Cornejo Lacroix intervino con esta ponencia: «La garantía de buen estado de navegabilidad en los contratos de fletamentos marítimo». No estamos, pues, ante un puro bizantinismo.

Si la razón del fletamento es el transporte de cierta mercadería, el primer trámite consiste en ponerla a bordo de la nave. El embarque de la cargazón, salvo caso aislado ${ }^{45}$ corre a cuenta del fletador. El lugar donde podía efectuarse se localiza tanto en el puerto de Sevilla (Las Muelas) como en todos aquellos parajes a orillas del Guadalquivir donde fondean las naves (Borrego, Horcadas, Bonanza) hasta llegar a su desembocadura en Sanlúcar de Barrameda. Cuando el contrato se otorga en Cádiz, o allí está surta la nave, la estiba se produce en la bahía. También es algo bastante común que un fletamento se contrate en Sevilla y

${ }^{44}$ AHPSPN, leg. 12386, fols. 1136r-1140r, carta de fletamento de Alonso Martín, Sevilla, 26 de octubre de 1566.

${ }^{45}$ AHPSPN, leg. 5926, fol. 372r-v, carta de fletamento de Juan Márquez, Sevilla, 9 de septiembre de 1560 . 
la nave reciba la carga en algún puerto de las islas Canarias. ${ }^{46}$ El fletante señala al fletador el plazo de tiempo en el que tiene que entregar las mercaderías a bordo del navío. Este plazo no es fijo, y depende tanto de la fecha de otorgamiento del contrato como de la fecha prevista para el comienzo del viaje según el calendario oficial de flotas. Aunque flexible, el incumplimiento de este plazo por parte del fletador le da derecho al fletante a hacerse a la vela sin recibir la carga contratada y, lo que es más importante, al cobro del flete en vacío. Esta cláusula de flete en vacío aparece en todas las escrituras de fletamento. Como norma general, el fletador debe abonar el precio del flete en vacío independientemente de si el fletante ha concertado otro fletamento en sustitución del que no ha tenido efecto por la no entrega de la mercadería. Pero en ocasiones la cláusula especifica que este flete en vacío únicamente es reembolsable cuando el fletante mantiene desocupado el espacio del fletamento incumplido, es decir, cuando el lugar que ocuparía la carga no embarcada se mantiene literalmente vacío en el transcurso del viaje. Así reza la cláusula que explica este razonamiento:

Y es condición que si dentro del dicho plazo no me diéredes la dicha carga, e si la flota se hiciese a la vela, que con dejaros el lugar vacío para la dicha carga, me pueda ir sin ella y me paguéis el dicho flete y averías por entero, como si os la llevara. ${ }^{47}$

En caso de que el fletador no entregue la mercancía, puede el fletante concertarse con otro cargador, con la condición de que si lo hace por un precio menor al del fletamento al que sustituye la diferencia ha de correr a cuenta del fletador que en origen

${ }^{46}$ AHPSPN, leg. 12380, fols. 452r-453v, carta de fletamento de Francisco de Abreu, Sevilla, 14 de febrero de 1565; AHPSPN, leg. 7776, fols. 364r-366r, carta de fletamento de Francisco Ruiz, Sevilla, 19 de octubre ded 1573; AHPSPN, leg. 16719, fols. 660r-662v, carta de fletamento de Domingo González, Sevilla, 20 de noviembre de 1581.

47 AHPSPN, leg. 9350, fol. 1050r-v, carta de fletamento de Diego de Torrijos, Sevilla, 15 de marzo de 1608; AHPSPN, leg. 14507, fol. 378r-v, carta de fletamento de Sebastián Jiménez de Enciso, Sevilla, 5 de marzo de 1622; AHPSPN, leg. 14507, fol. 767rv, carta de fletamento de Francisco Melgarejo, Sevilla, 9 de abril de 1622. 
no dio la carga. ${ }^{48} \mathrm{Si}$, por el contrario, es el fletador quien por causa justificada se ve obligado a concertarse con otro fletante, podrá hacerlo por un precio mayor al fletamento que sustituye, y la diferencia correrá a cargo del fletante, responsable en este caso del incumplimiento del contrato primitivo. ${ }^{49}$

Los fletamentos ofrecen escasos detalles sobre el contenido de la carga. A través de ellos no se confirma el supuesto cambio cualitativo - con perdón de Aristóteles- en las relaciones mercantiles entre España y las Indias del que algunos autores hablan. Se tiene por cosa probada que, a medida que avanza la segundad mitad del siglo XVI y se entra en el siglo XVII, gran parte de las cargazones dejan de componerse de productos agrícolas (vino y aceite sobre todo) a favor de productos manufacturados (textiles en especial). Estas manufacturas, de mayor valor intrínseco, ocuparían sin embargo menos volumen, con la consiguiente reducción en el tonelaje de las flotas. ${ }^{50}$ Pero los contratos de fletamentos no confirman esta idea.

A lo largo de nuestro periodo de análisis, la fórmula más común consiste en indicar que se fleta la nave por tantas toneladas, sin más pormenores. Cuando se detalla la composición de la carga, en la mayoría de los casos se habla de pipas y botijas de vino, y en raras ocasiones se explicita que una determinada porción de las toneladas deba integrarse por «ropa menuda» o «ropa de caja», 51 términos que designan a todos aquellos productos ajenos

${ }^{48}$ AHPSPN, leg. 9935, fols. 674r-676r, carta de fletamento de Pedro Martín, Sevilla, 23 de febrero de 1590.

49 AHPSPN, leg. 7787, fols. 743r-744r, carta de fletamento de Juan Núñez, Sevi1la, 30 de marzo de 1577; ibid., fols. 758r-759r, carta de fletamento de Pedro Sánchez, Sevilla, 1 de abril de 1577; AHPSPN, leg. 7789, fol. 1334r-v, carta de fletamento de Manuel de Rodas, Sevilla, 21 de abril de 1578; AHPSPN, leg. 7796, fols. 2024r-2025v, carta de fletamento de Alonso Pavón, Sevilla, 11 de agosto de 1580.

50 Véase García-Baquero González (1998), pp. 348-357.

51 AHPSPN, leg. 12368, fol. 1193r-v, carta de fletamento de Juan de Vanegas, Sevilla, 14 de septiembre de 1561; AHPSPN, leg. 5947, foliación rota, carta de fletamento de Diego de Alvendín, Sevilla, 20 de marzo de 1565; AHPSPN, leg. 3428, foliación rota, carta de fletamento de Diego Sánchez, Sevilla, 16 de mayo de 1566; AHPSPN, leg. 7764, fols. 1147r-1148r, carta de fletamento de Martín García, Sevilla, 1 de junio de 1570; AHPSPN, leg. 9936, fols. 203r-204v, carta de fletamento de Marcos del Castillo, Sevilla, 4 de junio de 1590. 
a la pipería y la botijería. Existen contratos que definen negativamente la cargazón. Gonzalo Báez Bello, por ejemplo, fleta su navío Nuestra Señora de Nazaret para que Esteban Pérez pueda meter en él hasta 10 toneladas de la «ropa y mercadería que quisiera, con que no sea hierro, brea, yeso, azulejos o botijas de vino».52

El flete es el elemento clave del contrato de fletamento. Veitia Linaje lo define como «el precio que se paga al dueño o maestre de navío por lo que lleva de un puerto a otro», y constituye la ganancia del naviero por su servicio de transporte. La cuantía final del flete resulta, por lo común, de la suma de dos conceptos y partidas diferentes, aunque a veces no disociables: el «flete» propiamente dicho y las denominadas - en algunos documentos- «averías de naos». ${ }^{53}$ Este último concepto nunca ha sido estudiado con fortuna. Salvo A.M. Bernal, ${ }^{54}$ que sigue a Veitia, todos los autores que se ocupan del fletamento a Indias confunden las averías de naos con la cantidad ad valorem que toda mercancía transportada a la ida y a vuelta en un barco de la Carrera debe pagar con el objetivo de financiar la defensa de las flotas frente al peligro de corsarios y piratas: la «avería» por excelencia del sistema comercial con las Indias. ${ }^{55}$ La causa de este yerro continuado en el tiempo procede más de la poderosa inercia historiográfica que de la falta de acceso a la documentación original. Manuel Lobo Cabrera, en un trabajo basado en contratos notariales, acude nuevamente a la tradición cuando llega el momento de analizar el concepto de avería en los fletamentos. ${ }^{56}$

El importe del flete incluye tanto el transporte de la carga como la responsabilidad del fletante sobre ella. Salvo que se señale otra cosa en el contrato, el naviero corre con el riesgo de toda

52 AHPSPN, leg. 7776, fols. 231r-232r, carta de fletamento de Gonzalo Báez Bello, Sevilla, 21 de octubre de 1573.

53 En concreto, tomo la expresión de Rojas Vaca (1996), pp. 340-343, carta de fletamento de Rafael Boquín de Bocanegra, Cádiz, 25 de abril de 1590. En otros casos, se habla simplemente de «averías».

54 Bernal Rodríguez (1993), p. 402.

55 Céspedes del Castillo (1945), pp. 519-520; Zumalacárregui (1945), pp. 6-12. Tampoco la más reciente puesta al día sobre la avería recoge las averías de naos: Luque Talaván (1998), pp. 135-142.

56 Lobo Cabrera (1993), pp. 123-126. 
la mercancía recibida a bordo de la nao y entra dentro de sus obligaciones el pago al cargador de los daños ocasionados a la cargazón en cualquiera de las etapas del viaje. Como el flete se paga casi siempre en Indias, el fletante solo toma el riesgo de la carga a cambio de una cantidad suplementaria, las «averías», que, como expresa Veitia, se cobra «por la seguridad y saneamiento que hace el maestre de entregar bien tratado lo que recibe o pagar los daños que tuviere». ${ }^{57}$ Algunos de los pocos ejemplos en los que el flete se abona en España, al contado o, en todo caso, en un plazo anterior al inicio del viaje, nos ayudan a comprender con mayor claridad la naturaleza de estas «averías de naos».

El 6 de mayo de 1581, Pedro de Palacios, apoderado de Álvaro de Colombres y Juan de Chagoya, concierta un fletamento con el jurado Diego Ortiz para que este pueda cargar en la nao San Salvador 12 toneladas de ropa y se naveguen hasta Santo Domingo; el precio del flete es de 20 ducados por tonelada, sin que por concepto de averías haya que pagar nada «porque se comprende en los dichos veinte ducados»; tras la firma del conocimiento de embarque, el fletador pagará 800 reales, y lo restante hasta cumplir el valor del flete, en el plazo de un mes. ${ }^{58}$ A principios de marzo de 1599, el gaditano Duarte de Quirós otorga un fletamento por el que Leonel de Cuadros podrá cargar 60 toneladas en pipas de vino, repartidas en lotes de 20 toneladas, en tres naves propiedad del dicho Quirós; por el transporte hasta Nueva España le cobrará 32 ducados de flete y averías, que se abonan en esta manera: en concepto de averías (a razón de 12 ducados por tonelada), 720 ducados al contado a vista del notario; y el resto (en concepto de flete a precio de 20 ducados por tonelada), librados en el banco de Pedro de la Torre Espinosa. ${ }^{59}$ Mes y medio más tarde, el capitán Diego Escobedo pide 34 ducados y medio en concepto de flete y averías por cada una de las 25 toneladas que Fernando Vallejo carga en la nao Nuestra Señora del Rosario,

\footnotetext{
57 Veitia Linaje (1672), Libro II, capítulo XVI, 3.

58 AHPSPN, leg. 7799, fols. 1175r-1176r, carta de fletamento de Pedro de Palacios, Sevilla, 6 de mayo de 1581.

59 AHPSPN, leg. 16762, fols. 28r-31v, carta de fletamento de Duarte de Quirós, Sevilla, 5 de marzo de 1599.
} 
y que ha recibido librado en el mismo banco antedicho. ${ }^{60} \mathrm{~A}$ fines de febrero de 1616, los capitanes Martín de Revillaga y Sebastián de Arteaga fletan sus respectivas naos a Gonzalo de Medina por idéntico precio, 39 ducados de flete y averías por cada tonelada, los cuales han recibido al contado. ${ }^{61}$

Estos cinco contratos de fletamento comparten dos rasgos. Por una parte, sus importes de flete son sustancialmente inferiores a lo que se está cobrando en sus respectivas fechas (1581, 1599 y 1616); y por otra, los pagos se abonan antes de realizarse el viaje, es decir, por adelantado al arrendamiento de obra que supone el fletamento. Se puede interpretar, pues, que las «averías de naos» (entendidas en este caso no como responsabilidad ante los daños sufridos en la carga, sino como emolumento suplementario al flete) constituyen una especie de recargo sobre el precio del transporte, el flete, a causa del aplazamiento del pago hasta la llegada al puerto de destino y entrega de la carga, bastantes meses después del otorgamiento de la escritura. Por esta razón, cuando el pago no se aplaza y el flete se reintegra en el mismo puerto de origen, no se exigen sobreprecios, y el flete, por sí mismo, incluye tanto el precio del transporte como el compromiso del fletante de indemnizar al fletador por los daños en la carga.

El lugar donde ha de abonarse las averías no tiene por qué coincidir con el de otorgamiento del contrato. En realidad, su pago se suele efectuar en la ciudad en cuyo término jurisdiccional se realiza el embarque de la cargazón. Aunque otorgado en Sevilla, el fletamento de Melchor Gutiérrez, señor y maestre del navío El Espíritu Santo, a Antonio Rodríguez de Cabrera declara que la carga de 60 pipas de vino se tiene que recibir en el puerto de Santa Cruz de Tenerife, y es allí donde se pagarán las averías. ${ }^{62}$ Algo parecido ocurre en el fletamento de Alonso Benítez a Gabriel de Rabasa, si bien en esta ocasión el lugar de otorgamiento es

${ }^{60}$ AHPSPN, leg. 9306, fols. 328r-329v, carta de fletamento de Diego de Escobedo, Sevilla, 23 de abril de 1599 .

61 AHPSPN, leg. 16844, fols. 112r-113v, carta de fletamento de Martín de Revillaga, Sevilla, 24 de febrero de 1616; ibid., fols. 181r-182v, carta de fletamento de Sebastián de Arteaga, Sevilla, 26 de febrero de 1616.

${ }^{62}$ AHPSPN, leg. 7781, fols. 890r-891v, carta de fletamento de Melchor Gutiérrez, Sevilla, 31 de agosto de 1575 . 
Cádiz y el lugar de embarque de la mercancía y pago de las averías es la isla de La Palma. ${ }^{63}$ Puede suceder que se reparta el reembolso de las averías entre el sitio en que se otorga la escritura de fletamento y el de embarque de las mercaderías. ${ }^{64}$ Como la recepción de la carga se produce a lo largo del río Guadalquivir en la mayoría de los casos de nuestra muestra, Sevilla es la plaza más veces elegida por el fletante para que el fletador le abone las averías. Cuando el embarque se produce en la bahía gaditana, la entrega del valor de las averías tiene lugar en Cádiz. Incluso cabe la posibilidad de que el fletante dé opción al fletador para que pague las averías en Sevilla o en Cádiz, según le convenga ${ }^{65}$

El plazo de pago de las averías conoce una casuística muy extensa: a la firma del conocimiento de embarque, ${ }^{66}$ antes de firmar los conocimientos, ${ }^{67}$ antes de que la nave se haga a la vela, ${ }^{68}$ cuando se acabe de recibir la carga, ${ }^{69}$ al avaluarse la embarca-

63 Rojas Vaca (1996), p. 302, carta de fletamento de Alonso Benítez, Cádiz, 4 de febrero de 1590 .

64 AHPSPN, leg. 12376, fols. 231r-232r, carta de fletamento de Juan Agustín, Sevilla, 13 de enero de 1564; AHPSPN, leg. 16844, fols. 534r-536v, carta de fletamento de Bartolomé de Fuentes, Sevilla, 7 de abril de 1616.

65 AHPSPN, leg. 16720, fols. 395r-396r, carta de fletamento de Duarte de Quirós, Sevilla, 21 de octubre de 1582.

66 AHPSPN, leg. 5947, fols. 167r-168r, carta de fletamento de Juan Francisco, Sevilla, 16 de enero de 1565; AHPSPN, leg. 7760, fols. 75-76r, carta de fletamento de Bernardo de Andino, Sevilla, 9 de octubre de 1568; AHPSPN, leg. 7762, fols. 313r-315r, carta de fletamento de Vasco Martínez, Sevilla, 2 de junio de 1569; AHPSPN, leg. 7771, fols. 1086v-1087v, carta de fletamento de Pedro de Flores, Sevilla, 28 de marzo de 1572; AHPSPN, leg. 7782, fols. 939v-940v, carta de fletamento de Pedro de Santiago, Sevilla, 15 de diciembre de 1575; AHPSPN, leg. 9236, fols. 540v-541v, carta de fletamento de Cristóbal Sánchez Melgarejo, Sevilla, 1 de febrero de 1584; AHPSPN, leg. 9339, fol. 402r-v, carta de fletamento de Bernardo de Paz, Sevilla, 13 de enero de 1606.

67 Rojas Vaca (1996), pp. 205-206, carta de fletamento de Pedro del Castillo, Cádiz, 8 de abril de 1560.

68 AHPSPN, leg. 12368, fol. 182r-v, carta de fletamento de Juan Vanegas, Sevilla, 9 de agosto de 1561; AHPSPN, leg. 5947, foliación rota, carta de fletamento de Álvaro de Colombres, Sevilla, 8 de enero de 1565.

69 AHPSPN, leg. 5926, fols. 182r-183r, carta de fletamento de Francisco Nero, Sevilla, 20 de agosto de 1560; ibidem, fol. 822r-v, carta de fletamento de Juan Rodríguez de Noriega, 8 de octubre de 1560; AHPSPN, leg. 5947, fols. 120v-121v, carta de fletamento de Juan de Palacios, Sevilla, 27 de enero de 1565; AHPSPN, leg. 16801, fol. 638r-v, carta de fletamento de Hernando Barbosa, Sevilla, 3 de marzo de 1609; AHPSPN, legl 16836, fols. 707r-708v, carta de fletamento de Lucas Urquiaga, Sevilla, 30 de enero de 1615. 
ción, ${ }^{70}$ cuando el fletante las pidiese, ${ }^{71}$ al contado en mano, ${ }^{72}$ al contado y libradas contra tercero, ${ }^{73}$ una parte al contado y otra a la firma de los conocimientos,$^{74}$ una parte al contado y otra al recibir la carga, ${ }^{75}$ una parte al contado y otra cuando se avalúe la carga, ${ }^{76}$ en un plazo estipulado de tiempo, ${ }^{77}$ etc.

Ya se ha señalado que la mayoría de los fletamentos estipulan que el pago del flete se haga efectivo en Indias. También para el abono del flete se declara un plazo, que comienza a correr una vez el fletante ha entregado la carga al fletador o a cualquiera de las personas consignadas en el conocimiento de embarque. El plazo más habitual es de 30 días, tiempo considerado como suficiente para que el cargador pueda vender sus mercaderías u obtener por otra vía dinero líquido con que abonar los fletes y otras deudas. Sin embargo, como se observa en el siguiente

70 AHPSPN, leg. 12384, fols. 864v-866r, carta de fletamento de Vicencio Centurión Garullo, Sevilla, 25 de febrero de 1566.

71 AHPSPN, leg. 7758, fols. 855v-857r, carta de fletamento de Salvador Hernández, Sevilla, 24 de mayo de 1568; AHPSPN, leg. 9339, fol. 398r-v, carta de fletamento de Bernardo de Paz, Sevilla, 13 de enero de 1606.

72 AHPSPN, leg. 12381, fos. 1149r-1150r, carta de fletamento de Blas González, Sevilla, 15 de diciembre de 1565; AHPSPN, leg. 7758, fols. 563r-564r, carta de fletamento de Martín de Utarte, Sevilla, 10 de abril de 1568; AHPSPN, leg. 12529, fols. 433v435r, carta de fletamento de Juan de Morales, Sevilla, 28 de abril de 1590; AHPSPN, leg. 16844, fols. 471r-473r, carta de fletamento de Sebastián Rodríguez de Carranza, Sevilla, 8 de marzo de 1616; AHPSPN, leg. 14507, fol. 767r-v, carta de fletamento de Francisco Melgarejo, Sevilla, 9 de abril de 1622.

73 AHPSPN, leg. 7758, fols. 221r-224r, carta de fletamento de Jerónimo de Ojeda, Sevilla, 4 de enero de 1568; AHPSPN, leg. 9237, fols. 961r-962r, carta de fletamento de Juan Rodríguez Quintero, Sevilla, 14 de marzo de 1584; Rojas Vaca (1996), pp. 305-307, carta de fletamento de Pedro de Aranedel, Cádiz, 12 de febrero de 1590.

74 AHPSPN, leg. 9339, fol. 292r-v, carta de fletamento de Antonio Hernández Barroso, Sevilla, 11 de enero de 1606.

75 Rojas Vaca (1996) pp. 337-340, carta de fletamento de Rafael Boquín, Cádiz, 16 de abril de 1590

76 AHPSPN, leg. 3428, foliación rota, carta de fletamento de Diego Sánchez, Sevilla, 16 de mayo de 1566; AHPSPN, leg. 12386, fols. 1136r-1140r, carta de fletamento de Alonso Martín, Sevilla, 26 de octubre de 1566; AHPSPN, leg. 16719, fols. 660r662v, carta de fletamento de Domingo González, Sevilla, 20 de noviembre de 1581; AHPSPN, leg. 16720, fols. 395r-396r, carta de fletamento de Duarte de Quirós, Sevi1la, 21 de octubre de 1582.

77 AHPSPN, leg. 9339, fol. 367r-v, carta de fletamento de Antonio Hernández Barroso, Sevilla, 12 de enero de 1606. 
cuadro 1, no conforman los 30 días el único plazo dispuesto en las escrituras de fletamento. Hasta la década de 1570 los plazos son particularmente variables, desde los 2 días hasta los 2 meses, sin que podamos determinar ninguna razón que explique tales diferencias, más allá de la libre negociación personal entre fletante y fletador.

\section{CUADRO 1}

PLAZOS PARA EL PAGO DEL FLETE EN INDIAS

\begin{tabular}{ccc}
\hline Plazos de pago & Frecuencia & Limites cronológicos \\
\cline { 3 - 4 } 2 días & 1 & 1560 \\
3 días & 1 & 1566 \\
8 días & 5 & 1562 \\
10 días & 1 & 1568 \\
12 días & 1 & 1563 \\
15 días & 14 & $1561-1590$ \\
20 días & 24 & $1560-1584$ \\
30 días & 167 & $1560-1622$ \\
39 días & 1 & 1584 \\
40 días & 4 & $1565-1570$ \\
50 días & 2 & $1572-1573$ \\
60 días & 4 & $1577-1590$ \\
Tras la descarga & 6 & $1560-1619$ \\
No se indica & 5 & $1567-1609$ \\
\hline
\end{tabular}

El análisis de los precios de los fletes y averías resulta difícil de evaluar. La mayor dificultad proviene, en este caso, de los propios defectos de la muestra, donde muchos años quedan sin datos y los años con datos se centran en un solo destino, todo lo cual no permite excesivas comparaciones. Sí podemos obtener tres ideas generales: excepto los primeros años de la década de 1560, el valor de los fletes para Nueva España y Tierra Firme suelen coincidir (hasta entonces parece que eran más onerosos los destinados a Nueva España); a lo largo de los 62 años que comprende nuestro trabajo se produjo un notable incremento en los precios de fletes y averías; a medida que se avanza en el siglo XVI los fletes y averías de una misma flota y de un mismo barco apenas oscilan entre sí, cuando no son idénticos. 
Normalmente, el precio del flete no distingue entre las distintas calidades de las mercaderías, y el único criterio es la unidad de volumen que ocupaba: la tonelada. Sin embargo, hay casos en que sí se diferencia el precio según se componga la tonelada de cargazón de ropa, pipas o botijas. En 1573, por ejemplo, Francisco Ruiz fleta la tonelada de pipas y botijas de vino a 28 ducados de flete, y la tonelada de ropa a 25 , en ambos casos con $4 \mathrm{du}-$ cados de averías. ${ }^{78}$ Algunos años más tarde, en 1584, Diego de Narea, señor de la nao San Marcos, concierta la tonelada de ropa menuda a 34 ducados de flete y 8 de averías, y la tonelada de botijas de vino y aceite, a 36 ducados de flete y 7 de averías. ${ }^{79}$

Carande considera habitual el precio de 12 ducados por tonelada para una cargazón a Indias en los últimos años del Emperador. ${ }^{80}$ De la misma cantidad habla el capitán Tomé Cano cuando comienza su vida profesional en la Carrera de Indias durante la década de 1560: «doce ducados de flete y dos de averías» por un viaje a Cartagena de Indias; en el momento que escribe su Arte (1609), el precio ha ascendido hasta "cuarenta ducados de flete y doce de averías» para el mismo destino. ${ }^{81}$ La realidad no corrobora la primera afirmación de Cano, aunque sí la segunda. En 1560 un fletamento hasta Nombre de Dios puede costar un total de 21 ducados, 18 de flete y 3 de averías. Aunque no tenemos datos de 1609, ya tres años antes, en 1606, los fletes para Nueva España se cobran a 52 ducados (40 de flete y 12 de averías), cifra que aisladamente se había conseguido en 1595 con destino a Nombre de Dios y que se mantiene en 1622, de nuevo con destino a Nueva España. Más que la descripción pormenorizada de la evolución de los fletes, resulta de mayor provecho ofrecer una explicación al comportamiento de estos en el seno de una misma flota y de un mismo navío.

Si atendemos exclusivamente a la historiografía elaborada hasta hoy, la carrera de Indias se nos presentará siempre como

78 AHPSPN, leg. 7776, fols. 364r-366r, carta de fletamento de Francisco Ruiz, Sevilla, 19 de octubre de 1593.

79 AHPSPN, leg. 9237, fols. 919r-920v, carta de fletamento de Diego de Narea, Sevilla, 8 de marzo de 1584.

80 Carande (1943), vol. I, p. 401.

81 Cano (1611), p. 95. 
un ámbito marítimo-mercantil poco propicio para la libre competencia entre sus actores económicos. Salvo excepciones, todos los autores hablan de la Carrera como un monopolio, al que califican de español, castellano, andaluz, sevillano, gaditano, etc., según la ocasión. ${ }^{82}$ El concepto de monopolio que emplean no está claro; en realidad no le sirve como base ninguna teoría económica decantada, por errónea que sea — ni del linaje marxista, ni de la familia neoclásica-, y por nada aparece un atisbo de teoría austriaca. Finalmente, «monopolio» no pasa de ser un sinónimo, más o menos acertado, de preeminencia, predominio o hegemonía, pero nada más. Tampoco los navieros y mercaderes actúan o toman decisiones en el relato de los historiadores, y cuando emergen en la narración parecen figuras de cartón-piedra. Aunque con ingenuidad, se emplea una visión estática del mundo, donde cualquier contratiempo paraliza, o no se conoce el error y el acierto.

La carrera de Indias fue una ruta marítima burocratizada desde el primer día —quién puede negarlo—; la Corona, o sea, el rey y sus intereses dinásticos, no le pierden ojo, pero esto no debe confundirse con ningún monopolio. Estaríamos interpretando torcidamente la realidad si considerásemos a la carrera de Indias o la propia Monarquía como un bloque. En la Carrera interactúan muchos «mercados», es decir, muchos conjuntos más o menos homogéneos de relaciones socio-económicas entre los distintos actores. A su vez, estos mercados no mantienen entre ellos vínculos armónicos, sino de conflicto, expresado en términos de competencia empresarial. De tales mercados, no siempre fácilmente definibles, solo en algunos — como el del azogue- puede afirmarse que se dé un acaparamiento exclusivo de recursos que justifique considerarlo como monopolio, al menos en el sentido que le otorga Kirzner. ${ }^{83}$ Ya sabemos por Mises que la burocracia es antigua, pero que en sí no puede asimilarse al totalitarismo soviético

82 Los ejemplos pueden contarse por miles. Si cruzamos en Google las expresiones «carrera de Indias» y «monopolio» nos dará más de 37.000 resultados. Desde un punto de vista académico, quizá sea José María Oliva Melgar el autor que más ha apostado por el «Monopolio» como bandera conceptual — vacua, es preciso decirlo. Como ejemplo, véase, Oliva Melgar (2004).

83 Kirzner (1973), passim. 
o nacionalsocialista del siglo XX. ${ }^{84}$ La máquina de poder de Felipe II y Felipe III no deja de incordiar a mercaderes y navieros de la carrera de Indias; aunque son pellizcos de monja. La Corona sabe que puede apretar poco, de ahí que las más de las veces se avenga a negociar con sus súbditos, sobre todo los más influyentes. Pero sabemos también que negociar con el Estado es llegar a un pacto con el Diablo: rentable a corto plazo, ruinoso al final. A pesar de las apariencias, el Estado suele mantener en la carrera de Indias su papel natural: servir de garante a las transacciones privadas, si bien no olvida la raison d'Etat (en demasiadas ocasiones más mediatizada por los intereses de los burócratas que los del propio rey: Leviatán no está libre de los problemas de agencia).

A partir de la séptima década del Quinientos, la libertad de acción casi completa de que hasta entonces disfrutaron mercaderes y navieros sufre un cambio. La saturación del mercado americano y el incremento del poder del Consulado de Sevilla provocan que no se admitan en la flota todas las naos en disposición física de hacerlo. El Consulado aquilata las toneladas que pueden absorber las colonias americanas y solicita al rey que la flota no supere determinado número de toneladas, lo que equivale a limitar el número de naos que pueden navegar hasta América de manera oficial. Este sistema más «cerrado» de flotas pudo tener dos importantes consecuencias para el negocio naviero. En primer lugar, el establecimiento de una dura competencia entre los señores de naos por obtener la visita para su embarcación, pugna en la que cada cual mueve los hilos a su disposición para obtener el favor del Estado, es decir, se extiende el proceso competitivo al ámbito de la política (de hecho, Madrid es cada vez más importante frente a Sevilla). Y en segundo lugar, el papel de la ley de la oferta y la demanda en el negocio de los fletes cambia algo su naturaleza, pues ya no compiten todas los barcos con todos, sino que el tonelaje de las naves elegidas coincide -en principio, aunque no siempre- con el tonelaje que solicita el Consulado. Aun así, no puede decirse que desaparezca la competencia. No

84 Mises (1944 y 1962), pp. 31-35. 
todos los señores de naos tuvieron el mismo éxito económico, lo que ya es un síntoma de que el negocio no se redujo a un simple reparto consensuado de la tarta de los fletes. Cada naviero ofrece lo suyo (la pericia de sus pilotos, la calidad de sus barcos, de sus tripulaciones, el buen cumplimiento de sus contratos de fletamento) y aprovecha sus oportunidades de ganancia: pone en práctica - como no puede ser de otro modo-su empresarialidad.

Los actores del negocio naviero - mareantes y cargadorestienen conciencia de que existe un precio de mercado con respecto a los fletes. Algunos contratos de fletamento no consignan el precio del flete en una cantidad exacta, sino «al precio a como se fletaren las demás pipas que se cargaren en la dichas mi nao o en otra cualquiera de la dicha flota», 85 «al precio y según y como se rompieren los fletes y averías de las pipas de vino que se cargaren en esta dicha flota», $86 \mathrm{o}$ "a como se abriere el precio en la plaza». ${ }^{87}$ Un economista neoclásico diría que los navieros se comportan como «precio-aceptantes» y que estaríamos en una estructura de mercado de competencia perfecta. Si además le añadimos que la mayor parte de los fletes mantienen un precio idéntico dentro de un mismo barco y una misma flota, el representante del mainstream verá consolidada su teoría sobre la perfección de la competencia en el mercado de fletes. Aunque si consultamos las cuentas de los señores de naos, donde suelen aparecer la relación completa de los fletes que llevan sus naves, encontraremos el fenómeno de la discriminación del precio. En la flota de Nueva España del año 1579, Juan García Comitre, maestre de la nao San Vicente, cobró la mayoría de los fletes a 24 ducados la tonelada de ropa y a 26 la de pipería; uno de los dueños del navío, Pedro Ramírez Olivos, pagó la tonelada de pipería a 24 ducados, y la de

85 AHPSPN, leg. 16754, fols. 782r-784v, carta de fletamento de Duarte de Quirós, Sevilla, 18 de abril de 1597; AHPSPN, leg.16836, fols. 727r-728r, carta de fletamento de Agustín de Paz, Sevilla, 31 de enero de 1615; AHPSPN, leg. 16836, fols. 827r-829r, carta de fletamento de Fernando Blas Montebernardo, Sevilla, 4 de febrero de 1615.

${ }^{86}$ AHPSPN, leg. 16765, fols. 619r-621v, carta de fletamento de Juan Martínez de Amilibia, Sevilla, 21 de enero de 1600; AHPSPN, leg. 16765, fols. 1081r-1083r, carta de fletamento de Pedro de Iturriza, Sevilla, 3 de febrero de 1600.

87 AHPSPN, leg. 14502, fol. 442r-v, carta de fletamento de Martín Freile, Sevilla, 27 de enero de 1621. 
botijas de aceite a 22: privilegios del propietario; Pedro López Muñoz cargó varias partidas de ropa a 23 ducados la tonelada; la mayor rebaja de la nao la obtuvo Bartolomé de Villavicencio, alférez en la dicha flota, quien llevó cinco toneladas de pipas a solo 16 ducados por tonelada. ${ }^{88}$ Juanes Ayate, maestre de la nao Nuestra Señora de la Consolación, cobró sus fletes a 33 y 32 ducados por tonelada en la flota de Nueva España de 1589. ${ }^{89}$ En 1615, 40 de las 456 toneladas de mercancías que cargó la nao Santa María y San Vicente, propiedad de Juan Álvarez y Sebastián de Arteaga, pagaron a razón de 44 ducados de flete y 12 ducados de averías, mientras que por las restantes se dieron 40 ducados de flete y las mismas averías. ${ }^{90} \mathrm{~A}$ la luz de estas circunstancias, la visión estática del economista neoclásico le hará decir que no, que teniendo en cuenta las trabas que siempre pone la Corona y la discriminación de precios, estamos ante una estructura de mercado de tipo monopolístico. La escuela austriaca, sin embargo, no precisa de tales formalismos pasivos, y sabe bien que aunque en estos contratos la determinación del precio del flete se haga remitir a otros externos al propio contrato, o que sean distintos en un mismo buque, finalmente reflejará la concordancia de la valoración intersubjetiva entre fletante y fletador en un servicio - el transporte de mercancías - en el que ambas partes creen salir beneficiadas. ${ }^{91}$ Entendida como proceso creativo y temporal, la competitividad en cualquier sector económico es casi inagotable. Allí donde se ejerce la empresarialidad está presente la competencia.

Los contratos de fletamentos especifican con claridad en qué moneda se han de pagar los fletes en Indias. Excepto cuando el puerto de destino es un lugar donde escasea la plata, siempre es

88 Archivo General de Indias (en adelante AGI), Contratación, leg. 718, N. 8, pleito de Pedro Ramírez Olivos y Hernán Rodríguez Botaya contra Juan García Comitre, sobre las cuentas de su nao, 1580.

89 AGI, Contratación, leg. 740, N. 3, cuentas de la nao Nuestra Señora de la Consolación, 1589.

90 AGI, Contratación, leg. 794, N. 5, pleito de Juan Álvarez contra Sebastián de Arteaga, sobre las cuentas de la nao, 1615.

91 Eugen von BöHM-BAWERK, «La ley básica de determinación del precio», Jesús Huerta de Soto (compilador), Lecturas de Economía Política. Volumen I, 3. a edición, Unión Editorial, Madrid 2009, pp. 99-142. 
este metal el exigido para el abono de los fletes, y desde muy pronto surge en la documentación el problema de las diversas formas de circulación de la plata en América. Hasta la década de 1580 no comienza la preferencia por los pagos en moneda acuñada (reales), si bien a lo largo de todo el periodo de estudio conviven los pagos en las distintas formas que toma la plata: corriente, ensayada, quintada, en barra, etc. De cualquier modo, los contratos presentan una variada casuística en sus expresiones y condiciones del pago, algunas de las cuales merecen reseñarse. Juan Francisco, señor y maestre de la nao San Sebastián, exige el pago de su flete «en oro de quilates o en plata ensayada o en barras»; $; 2$ Francisco de Morales Camacho, «en plata ensayada». ${ }^{93}$ Algunos fletantes, aunque no piden monedas, al menos se previenen contra la posible ley inferior de la plata en pasta o el descuento que le suponga en Sevilla el señoraje; Francisco Abreu quiere el embolso de su flete «en pesos de oro y plata ensayada y marcada que vendido en esta dicha ciudad de Sevilla valga trescientos y setenta y cinco maravedís cada uno». ${ }^{94}$ Especialmente desconfiado se muestra Pedro de Santiago, quien desea que se le abone su flete «en oro de quilates o plata ensayada, y no en plata corriente aunque sea con intereses». ${ }^{95}$ Cuando se solicita expresamente el pago en moneda acuñada, el contrato lo consigna sin ambigüedad: «en reales de plata»; 96 o de manera algo más confusa: «en reales de plata y no en plata». ${ }^{97}$ Igualmente, se puede exigir con cierta

\footnotetext{
${ }^{92}$ AHPSPN, leg. 5947, fols. 167r-168r, carta de fletamento de Juan Francisco, Sevilla, 16 de enero de 1565 .

93 AHPSPN, leg. 12380, fols. 935r-v, carta de fletamento de Francisco de Morales Camacho, Sevilla, 21 de marzo de 1565.

94 AHPSPN, leg. 12380, fols. 365r-366v, carta de fletamento de Francisco Abrey, Sevilla, 3 de febrero de 1565. La misma condición impone Juan de Vanegas: AHPSPN, leg. 12368, fols. 812r-v, 872r-v y 949r-v, cartas de fletamento de Juan de Vanegas, Sevilla, 9, 18 y 27 de agosto de 1561.

95 AHPSPN, leg. 7782, fols. 939v-940v, carta de fletamento de Pedro de Santiago, Sevilla, 15 de diciembre de 1575 .

96 AHPSPN, leg. 9335, fols. 671r-673r, carta de fletamento de Pedro Martín, Sevilla, 23 de febrero de 1590.

97 AHPSPN, leg. 16720, fols. 667r-668r, carta de fletamento de Felipe de Gaya, Sevilla, 13 de noviembre de 1582; AHPSPN, leg. 9237, fols. 904r-905v, carta de fletamento de Vasco Martín, Sevilla, 20 de febrero de 1584.
} 
rotundidad: «en reales de plata y no en otra moneda», ${ }^{98} \mathrm{o}$ con bastante contundencia: «en reales de plata de contado y no en otra forma de paga ni moneda alguna». ${ }^{99}$ Algunos fletantes llegan al punto de exigir un precio de flete más alto si la paga no se hace en reales de plata: «y otrosí es condición que el dicho flete se ha de pagar en reales de contado y no en otra manera; y si de otra manera se pagase, que se paguen cuatro ducados más por tonelada», dice el fletamento que Alonso López de Escamilla otorga en nombre del capitán Andrés Felipe, señor de la nao Santa Catalina, con destino a Nueva España. ${ }^{100}$ En los fletamentos con destino a Santo Domingo o Puerto Rico, islas de pobre presencia de metal argénteo, se estipula que el pago del flete se hará «en pesos en cuartos, moneda de la dicha Isla Española», ${ }^{101} \mathrm{o}$ "en pesos de moneda corriente que corre en la ciudad de San Juan de Puerto Rico», ${ }^{102}$ elaboradas en vellón. ${ }^{103}$ Como vemos, la tabla de conversión oficial del dinero - la moneda de cuenta- es una cuestión del Estado, pero el valor del medio real de intercambio - el contante y sonante- se trata de un asunto privado en el que la Corona poco tiene que decir a la hora de la verdad.

\footnotetext{
98 AHPSPN, leg. 16801, fol. 565r-v, carta de fletamento de Luis Ortiz, Sevilla, 11 de marzo de 1609; AHPSPN, leg. 16837, fols. 742r-745r, carta de fletamento de Gaspar Menéndez de Navia, Sevilla, 6 de marzo de 1615.

99 AHPSPN, leg. 16812, fol. 452r-v, carta de fletamento de Pedro de Vargas, Sevi1la, 18 de abril de 1611 .

100 AHPSPN, leg. 16720, fols. 508r-509v, carta de fletamento de Alonso Pérez de Escamilla, Sevilla, 5 de noviembre de 1582. Otras cinco cartas contenidas en dicho legajo y otorgadas igualmente por Alonso Pérez de Escamilla declaran idéntica condición.

101 AHPSPN, leg. 7761, fols. 605r-606r, carta de fletamento de Pedro Camiña, Sevilla, 10 de febrero de 1569; AHPSPN, leg. 7762, fols. 313r-315r, carta de fletamento de Vasco Martínez, Sevilla, 2 de junio de 1569; AHPSPN, leg. 7776, fols. 231r232r, carta de fletamento de Gonzalo Baéz Bello, Sevilla, 21 de octubre de 1573.

102 AHPSPN, leg. 12375, fols. 59r-60v, carta de fletamento de Juan de Dueñas, Sevilla, 29 de julio de 1563; AHPSPN, leg. 7758, fols. 12r-15r, carta de fletamento de Pedro de la Fuente, Sevilla, 30 de diciembre de 1567.

103 Sobre los problemas monetarios en Santo Domingo durante el siglo XVI, véase Serrano Mangas (1992).
} 


\section{$\mathrm{V}$ \\ ¿TASACIÓN O LIBERTAD DE FLETES?}

El rasgo básico de toda política mercantilista en sus distintas fases de desarrollo fue el intervencionismo estatal en los asuntos económicos. ${ }^{104}$ En el caso español, ningún ejemplo es tan claro como el de la carrera de Indias, cuya evolución siempre estuvo condicionada por las decisiones de la Corona. La actuación del Estado estuvo guiada por una jerarquía de intereses a los que hubo que dar satisfacción para que el sistema socioeconómico de tipo estamental pudiera perpetuarse. Una muestra del apoyo estatal a un determinado grupo en perjuicio de otro lo constituye la política de tasación de fletes, sobre la cual se han vertido algunas opiniones poco escrupulosas. 105

Fue Antúnez y Acevedo, en 1797, el único autor que se preocupó por este interesante problema para la historia de la marina mercante y el negocio naviero en la carrera de Indias. ${ }^{106}$ Antúnez completó las lagunas de información de que adolecía Veitia Linage; los autores posteriores, se limitaron a repetir las noticias que ofreció hace más de dos siglos. Ahora, los documentos de archivo, y sobre todo el interés por su estudio, vienen a completar el panorama. No está de más, tras tanto tiempo de olvido, exponer por extenso lo relativo a esta materia.

Hasta el año 1572, el precio de los fletes se rige por la ley de la oferta y la demanda, por llamarlo de alguna manera. A mayor número de naos disponibles para hacer la travesía transoceánica y menor cantidad de mercancías que cargar, los precios disminuyen; a mayor cantidad de mercancías y menor disponibilidad de barcos, los fletes se elevan. La calidad de las naves también incide en el precio del flete; un barco fuerte y bien acondicionado puede permitirse ofrecer fletes altos, ${ }^{107}$ mientras que buques viejos

104 Eric Roll, Historia de las doctrinas económicas, México, Fondo de Cultura Económica, 1974 [ed. orig. 1939], p. 36.

105 Bernal Rodríguez (1993), pp. 154-155 y 402-403.

106 Antúnez y Acevedo (1797), pp. 169-174.

107 «Primeramente, si tienen noticia de la dicha nao nombrada San Francisco y si saben que es de porte de seiscientas toneladas de merchante, nueva del primer viaje y fuerte y velera, y de tan buenas maneras y calidades que todos los mercaderes y 
y destartalados, habiendo otros mejores, sólo consiguen fletes de escasa cuantía. Tampoco escapó el negocio naviero a la revolución de los precios; si el señor de nao tiene que gastar más capital en el apresto y abastecimiento del barco, igualmente ofrece fletes más elevados para mantener el margen de ganancias. Aunque la ley de costes resulta bastante imperfecta, el naviero cree que debe asumir una serie de gastos irrenunciables si quiere cumplir la reglamentación - otra cosa es que decida hacer caso omiso, lo que resulta comprensible. La valía profesional del naviero no puede olvidarse; los cargadores prefieren entregar sus mercancías a señores y maestres de nao de confianza, conocedores de su oficio, estrictos en el trabajo y con experiencia en los viajes ultramarinos; también están dispuestos a pagar un flete superior cuando así ocurre. En cualquier caso, como aclaraba Antúnez y Acevedo, durante «los primeros años, y algunos después de su establecimiento - se refiere a la carrera de Indias-, el convenio de las partes, y el uso o costumbre, eran la única regla para los contratos de fletamento.»108

Las cosas comienzan a cambiar a principios de la década de 1570. Poco tiempo antes, el 3 de mayo de 1569, Felipe II ordenó a los oficiales de la Casa de la Contratación que redujesen la flota con destino a Nueva España a cinco o seis naos. Como la reducción del número de barcos hace previsible que sus propietarios decidan subir los fletes, también se les pide a los jueces de la Casa, con el parecer del Consulado, que tasen y moderen los fletes «para que por la necesidad no haya exceso en los dichos precios». ${ }^{109}$ Todo quedó en palabras; esta vez las disposiciones regias no pasaron de ahí, pero se barruntan transformaciones.

Fue un golpe bajo para los señores de naos de la Carrera de Indias. Por cédula firmada en el Pardo el 12 de abril de 1572, el Prudente mandó que la Casa de la Contratación tasase los fletes

pasajeros han procurado y solicitado con mucha instancia cargar en ella sus mercaderías para ir en ella pagando fletes muy aventajados por ser la dicha nao nueva y de las calidades que está dicho» (AGI, Contratación, leg. 4801. Testimonio de autos del capitán Juan de Chagoya, Sevilla, 29 de enero de 1587).

108 Antúnez y Acevedo (1797) p. 169.

109 AGI, Justicia, leg. 1151, N. 2, R. 1, copia de real cédula a la Casa de la Contratación, Madrid, 3 de mayo de 1569. 
en la flota de Nueva España. Ahora no hay marcha atrás: la orden debe cumplirse. ${ }^{110}$ Pero no fue un simple capricho del rey.

El prior y cónsules de la Universidad de Mercaderes de Sevilla han acudido al Consejo de Indias para mostrar una relación donde se quejan con amargura de los precios que van adquiriendo los fletes. También jugaron con el desconocimiento que tenían las instituciones centrales de los asuntos marítimo-mercantiles de la Carrera. Les hicieron ver que los fletes habían excedido «la orden y costumbre» que hasta esos días se había guardado en los precios; y que éstos eran tan elevados «que venían a montar los fletes tanta cantidad como la ganancia que de [las mercancías] se podría sacar». Suplican que el rey ordene una tasación de los fletes, pues si no se acude a este remedio tendrán que abandonar el trato con las Indias. El Consejo de Indias, asustado por lo que oyen del prior y cónsules, no duda en darles la razón y en solicitar del monarca la cédula que solucione las desgracias de estos pocos pero tan fieles servidores.

El día 5 de mayo de 1572 llega la real cédula de la discordia a manos de los oficiales de la Casa de la Contratación en Sevi1la. Dos días más tarde, se reúnen en la sala de la Audiencia de la Casa con los representantes máximos del Consulado y algunos de los dueños y maestres de las naos que se aprestan en ese momento para ir a Nueva España: los hermanos Antón y Cristóbal Sánchez de Armas, Ortuño de Bilbao la Vieja, Diego Ochoa, Felipe Boquín y Juan García Cómitre. No deben de tener estos muy claro el asunto que va a discutirse en la reunión, pues a los argumentos iniciales que emplean para defender una subida en el precio de los flete le sobran muchos titubeos. Alegaron que todo era consecuencia de la prohibición de las urcas en la Carrera. Sus dueños se vieron obligados a venderlas a bajos precios y a adquirir naos vizcaínas de elevado coste; además, ese año, los calafates y carpinteros de ribera cobraron jornales más crecidos en las carenas. Ante esta reacción tan tibia por parte de los

110 AGI, Patronato, leg. 251, R. 69, copia de real cédula a la Casa de la Contratación, El Pardo, 12 de abril de 1572. Mientras no se indique lo contrario, el resto de noticias acerca de la tasación de fletes para la flota de Nueva España en 1572 provienen del mismo legajo y ramo. 
navieros, los jueces de la Casa no esperan más tiempo para tasar los fletes: 31 ducados por tonelada de pipería y 29 ducados por tonelada de ropa; en ambos casos se les añade un máximo de cuatro ducados de avería por cada tonelada.

Los dueños de naos confiaron en que la tasa sólo tendría validez para los fletamentos concertados a partir de esa fecha, que su efecto no fuera retroactivo; pero la esperanza duró poco. Tras la imposición de la tasa se dispuso que ningún maestre ni dueño de nao pudiera pedir más dinero del señalado en la tasación, aunque ya hubieran otorgado cartas de fletamento a mayor precio; tampoco debían hacer firmar a los mercaderes conocimientos de embarque donde se estipulasen fletes superiores a los tasados.

Entre la sorpresa inicial y la reacción pasan cinco días. El 12 de mayo, los dueños de naos afectados por la tasa presentan en la Contratación el primer alegato contra el menoscabo de sus intereses. En primer lugar, muestran su agravio por no haber sido escuchados en la tramitación de un expediente que tanto les afectaba; de hecho, ni siquiera se les había notificado la real cédula de 12 de abril. No consideran dignas de crédito las palabras y razones de los cargadores a Indias que, como partes interesadas, acudieron al Consejo con una «relación siniestra» $\mathrm{y}$, sobre todo, mintieron con descaro: ¿desde cuándo en la Carrera de Indias ha existido un precio de flete "acostumbrado»?, ¿acaso el importe de los fletes no son fruto de la negociación entre maestres y mercaderes? Señalan que con la tasación ninguna persona comprará barcos grandes y fuertes, de altísimos costes, sino naves pequeñas y viejas para reducir al mínimo los gastos. Si los materiales necesarios para el avío de la nao (madera, estopa, brea, jarcia, velas, etc.) no paran de encarecerse, ¿cómo puede limitarse la casi única fuente de ingresos, los fletes? En ese caso, creen que también es de justicia tasar los productos que consumen las naves.

Tras estos argumentos, más sólidos que los de la primera cita, piden a la Casa de la Contratación que admita una apelación contra la tasa de fletes. La Casa, que no puede negarse, les concede la petición. Nueva esperanza frustrada. Pensaron los señores de naos que con la admisión de la demanda se suspendería la tasa; y que a la vista de la lentitud de la justicia y otras cuestiones administrativas, habría tiempo para que se diese a la vela 
la flota sin haber tenido efecto la tasación. Calcularon mal: el 21 de mayo se pregonaron en las Gradas las medidas que salieron de la primera reunión.

Pero se empeñaron en no claudicar. A pesar de las reconvenciones, los señores de naos persisten en desobedecer las órdenes reales. Dejan bien claro sus amenazas a los mercaderes: o les pagan 34 ducados por tonelada y 4 ducados de avería, o no firman los conocimientos de embarque. Además, se dedicarán a descargar las mercancías ya embarcadas. Esta postura de fuerza indignó a los comerciantes, que de nuevo se presentaron ante la Casa para solicitar justicia. El ambiente entre mercaderes y navieros se va enrareciendo. Esteban López, cargador en las naos de la flota, reclama que no se permita salir de la ciudad a los maestres y dueños de naos que no hayan firmado los conocimientos, y deja caer que la flota ya se está retrasando demasiado a causa tantos problemas, con los peligros que siempre conllevan las salidas tardías. Antonio de Villanueva, otro cargador, expone las cantidades que pretenden cobrarle los maestres: Pedro de Paredes, 32 ducados y 4 de avería por tonelada; Juan García Cómitre, 33 ducados por tonelada más 4 de avería; Ortuño de Bilbao la Vieja, por 20 pipas de vino, 34 ducados y 4 de avería por tonelada, y por diez doceavos de tonelada de ropa, 32 ducados más 4 de avería; Gabriel de Herrera, por dos toneladas y media de botijas de aceite, 31 ducados y 6 de averías por tonelada; Antón Sánchez de Armas, que no quiere ni hablar por menos de $34 \mathrm{du}-$ cados y 4 de averías por tonelada. Además de estas cantidades, abusivas a los ojos de los mercaderes, el principal escollo reside en que los dueños de naos amenazan con alijar la carga ya embodegada. A esas alturas del enfrentamiento, Ortuño de Bilbao la Vieja se niega a recibir cargamento alguno al precio que fuera; aduce que su nao está repleta y no sabe dónde meter más mercancía.

La Casa de la Contratación se percata que la situación, cada vez más enconada, se le escapa de las manos. No tiene más remedio que actuar con contundencia. Dicho y hecho. En primer lugar, ordena que no se descargue nada de las naos y que los daños que sufran las mercancías corran a cuenta de los maestres. Sólo unas horas más tarde, el mismo día 29 de mayo, da el paso más doloroso: hay que prender a todos los maestres para encerrarlos en 
la cárcel tras el continuo quebrantamiento de una norma dictada por el propio rey. Al día siguiente, sin embargo, todos los maestres, menos Diego Ochoa y Antón de Fuente, han logrado huir de Sevilla. Ante este atrevimiento, los oficiales de la Casa ordenan embargar los bienes de los navieros huidos para forzarlos a comparecen ante las autoridades. Otra vuelta de tuerca en las medidas de presión por parte de la Casa: si los maestres persisten en alargar su huída, se nombrarán a distintas personas para que se hagan cargo de las naos de Nueva España; la flota saldría con o sin maestres. La medida surte efecto y solo un par de días después se presentan los fugitivos en la Casa. No les quedó otra alternativa que cumplir con la tasa. El conflicto concluye; la tasa de los fletes permanece como al principio: 31 ducados por tonelada de pipas y 29 por tonelada de ropa, más 4 de avería.

Terminaron los desórdenes y disputas en la flota de Nueva España, que se dio a la vela el 12 de junio de 1572. ${ }^{111}$ Pero el precedente no tranquiliza a los señores y maestres de las naos que se despachan para la flota de Tierra Firme; intuyen que nada bueno se les viene encima: y no están equivocados.

El 18 de julio de 1572 comparece Sebastián Navarro, procurador del Consulado de Sevilla, ante los oficiales de la Casa de la Contratación. Lleva en sus manos una real provisión, otorgada en Madrid el 4 de julio, por la que se ordena a la Casa que al igual que se hizo con la flota de Nueva España se haga ahora con la de Tierra Firme: la tasación de los fletes. ${ }^{112}$ Tras la lectura del mandamiento real, la Casa ordena que el día 21 de julio, a las tres de la tarde, acudan a la sala de la Audiencia de la Contratación el prior y cónsules y los maestres de la flota de Tierra Firme.

Se congregaron, ante la mirada vigilante de los jueces de la Casa, Diego Díaz Becerril, prior del Consulado, Alonso de Cazalla de León, cónsul, y Antonio Rodríguez de Cabrera, por ausencia del otro cónsul, Francisco Martínez de Baeza; junto con ellos,

111 Chaunu (1955-1960), vol. III, p. 166.

112 Todas las informaciones sobre la tasación de los fletes de la flota de Tierra Firme de 1572 se encuentran recogidas en: AGI, Justicia, leg. 1151, N.2, R.1. Mientras no se indique lo contrario, las noticias que se exponen sobre este asunto han salido del mismo legajo, número y ramo. 
un pequeño grupo de cargadores en la flota de Tierra Firme: Juan Antonio Corzo, Pedro de Sepúlveda, Juan Alonso de Medina, Francisco Sánchez de Melo, Juan Flores Taboada, Rodrigo de las Casas y Bartolomé de Jerez. Frente a estos, algunos dueños y maestres de nao de la dicha flota: Cristóbal Montebernardo, Gaspar Fernández, Alonso de Chaves, Marcos de Nápoles, Pedro de Alburquerque, Baltasar Núñez, etc. (esta vez sí conocen el motivo de la convocatoria). Y se reabrió de nuevo el desencuentro. Los mercaderes vuelven a insistir en que los excesivos fletes les impedirán obtener ganancia alguna en las mercancías; además, recuerdan que aunque la real cédula de 12 de abril se refería exclusivamente a la flota de Nueva España, su espíritu puede extenderse a cualquier otra. Por su parte, los dueños de naos justifican la subida de los precios de los fletes porque «las naos cuestan mucho más que antes y lo mismo la jarcia y velas y todos los aparejos»; reiteran, además, la elevación que los jornales de calafates y carpinteros de ribera tuvieron ese año. Otra vez acuden al argumento de la imputación de costes.

Los oficiales de la Casa hicieron oídos sordos a las razones de los mareantes y determinaron, como disponía la voluntad del rey, llevar a efecto la tasación de los fletes de Tierra Firme: por cada tonelada de pipería (o botijas), 29 ducados; la tonelada de ropa quedó en 24 ducados; más 4 ducados de avería en cada tonelada. Como la ocasión precedente, la Casa compele a que los dueños de naos no cobren más precio del tasado no obstante hubieran firmado contratos de fletamentos más onerosos; tampoco les permite que obliguen a los mercaderes a firmar conocimientos ni escritura alguna que fuera contra la tasa, «aunque se diga y pretenda que los dichos mercaderes lo hicieron de su propia voluntad y sin serles pedido de parte de los dichos maestres; y si lo firmaren no sean válidos». Cada incumplimiento de esta orden conllevaría una pena de 100.000 maravedís y la suspensión en el oficio de maestre por dos años. Antes de finalizar la reunión, la Casa comunica que en los días próximos acudirán todos los maestres de las naos a la sala del Consulado para avaluar las mercancías que tienen cargadas y firmar los conocimientos de embarque; cada jornada de retraso se multaría con 10 ducados. 
Con la lección aprendida del calvario que vivieron sus colegas el mes anterior, no hubo ahora entre los navieros comportamientos de abierta rebeldía. La posibilidad de pasar unos días en la cárcel de la Casa, tan poco recomendable para la salud y el honor, provocó que no fuesen más allá del cruce de acusaciones e intentaran conseguir la revocación de la tasa por medio de la palabra. Aun cuando todo resultó inútil, merecen señalarse algunos de los argumentos utilizados por lo que aporta al conocimiento del negocio naviero, su situación coyuntural y la diferencia que los propios protagonistas veían entre la ruta de Nueva España y la de Tierra Firme.

Juan de la Peña, en nombre de la Universidad de mareantes, estima que además de ser gravosa la tasa de por sí, el precio de los fletamentos con destino a Tierra Firme se fijó, para colmo, por debajo de los de Nueva España. Esta decisión no la tiene por justa, pues si desde el virreinato novohispano las naos vuelven a Castilla cargadas de cueros, lana, cochinilla y otros frutos de la tierra, ganando fletes de vuelta, «las naos de Tierra Firme vuelven a España vacías porque de Tierra Firme no se traen mercaderías a España»; de ahí que pidiera la revisión la tasa, estableciéndose más alta. Mientras en Nueva España las naos desembarcan las cargazones en barcas de la zona, en Tierra Firme se efectúa la descarga de las naos con los propios bateles y chalupas, con enorme costa y riesgo para las mercancías, «y acontece consumirse todos los fletes en pagar daños». La salida de la flota de Nueva España en fecha anterior a la de Tierra Firme contribuye a vaciar Andalucía de pertrechos y bastimentos para las restantes naos, con la consiguiente alza de precios que se ven obligados a sufrir los dueños y maestres de las naves destinadas a Tierra Firme. Incluso, como remate, la plata que se recibe en Nueva España como pago por los fletes posee una mejor calidad que la que se obtiene en Tierra Firme. Si a todo esto se une los efectos de la revolución de los precios en buena parte de todas las actividades y transacciones económicas, se explica que

si en otros tiempos fuera tolerable tasar o llevar veinte e cuatro ducados por tonelada e cuatro de averías, ahora no se sufren ni 
se pueden pedir por menos de treinta e cuatro ducados de flete por cada tonelada e seis de averías.

Los cargadores, por su lado, defienden a capa y espada sus intereses particulares y ven en la tasación de los fletes la única manera de continuar sus negocios en la carrera de Indias:

porque va cada día creciendo tanto la codicia de los maestres y pilotos que si no se pusiese límite y tasa a los fletes que llevan, cesaría el trato y comercio de las Indias, porque es más lo que piden de fletes que el interés y aprovechamiento que hay en las mercaderías, y así están los maestres y pilotos muy ricos y los cargadores pobres; y si algún maestre está pobre, son los que los dueños de navíos ponen para que sirvan por cierto sueldo, pero los señores de navíos que llevan los fletes y el interés, todos están muy ricos.

A pesar de estas palabras, sin duda exageradas, no todo era jauja en el negocio naviero. Pero quién se atreve a negarles a los mercaderes de Indias ardor en la defensa de sus empresas frente a los maestres y señores de naos, personajes tan necesarios como denostados a los ojos de los cargadores.

Tras numerosas peticiones de los dueños de naos, el Consejo de Indias determinó, el 14 de agosto de 1572, que todos los fletamentos negociados antes del 31 de julio se mantuvieran conforme a las tasas prescritas, es decir, a 29 ducados la tonelada de pipas y a 24 la de ropa, más los 4 ducados de averías; pero que los fletamentos otorgados desde primeros de agosto se incrementaran en un ducado por tonelada, más 4 de averías: la tonelada de pipas a 30 ducados y la de ropa a 25. Nueve días después, el 23 de agosto, la flota emprendió su viaje con la buenaventura hacia Tierra Firme. ${ }^{113}$

¿Realmente acataron la tasa de los fletes los maestres y señores de naos? Los datos demuestran que sí; incluso en ocasiones los precios eran bastante inferiores de lo que determinaba la ley; no hay que olvidar que la tasa era un precio máximo y las condiciones

113 Chaunu (1955-1960), vol. III, p. 168. 
del mercado de flete podían contribuir a bajarlos. Así, por ejemplo, en agosto de 1577, el burgalés Juan Alonso de Medina se obliga a pagar a Gaspar Díaz, maestre de la nao Santa María de Bego$\tilde{n} a, 18$ ducados la tonelada de botijas, más 4 ducados de avería, por el fletamento de 500 botijas de vino que le ha de transportar hasta Nombre de Dios en compañía de la flota de Tierra Firma al mando del general don Juan de Velasco de Barrio. ${ }^{114}$ Una muestra manifiesta de que en 1579 la tasa sigue vigente aparece en los libros de sobordo de la nao San Vicente, de 350 toneladas, propiedad de Pedro Ramírez Olivos y Hernán Ramírez Botaya, maestre Juan García Cómitre, que viajó en la flota de Nueva España del general Juan de Villavicencio. Entre las partidas de fletes, una de ellas dice que

Por el flete de tres toneladas de ropa que cargó Juan de Morales para Rodrigo del Castillo, a veinte y cuatro ducados tonelada, porque aunque viene el precio a veinte y seis ducados, no se pagó más por la cédula de Su Majestad que dice a veinte y cuatro ducados toneladas. ${ }^{115}$

No fue la única partida que expresaba la existencia de la tasa:

Por el flete de cuatro dozavos de ropa que cargó el dicho [Pedro López Muñoz] para Mateo de Fuentes a razón de a veinte y cuatro ducados tonelada, monta tres mil maravedís, porque aunque venía a veinte y seis ducados no quiso pagar más conforme a la cédula de Su Majestad. ${ }^{116}$

Y un último ejemplo en el mismo navío:

Por el flete de seis dozavos de ropa que cargó Gonzalo de Aguilera para Gaspar de Covarrubias, a razón de a veinte y cuatro

114 AHPSPN, 7788, fols. 743v-745v, carta de fletamento de Gaspar Díaz, Sevilla, 21 de agosto de 1577.

115 AGI, Contratación, leg. 718, N.8, pleito de Pedro Ramírez Olivos y Hernán Ramírez Botaya contra Juan García Cómitre, sobre las cuentas de la nao. 1580. 116 Ibid. 
ducados tonelada, porque aunque venía a veinte y seis ducados, no pagaron más por la cédula de Su Majestad. ${ }^{117}$

En 1582, empero, se anuló la tasa establecida una década antes. En el penúltimo párrafo de las ordenanzas para el despacho de flotas a Indias de 20 de enero de ese año, se establece por voluntad regia que a partir de entonces, y mientras no se indique lo contrario, deja de tener efecto las tasas en los fletamentos, a causa del «crecimiento en que iban las cosas, y costas que tienen las naos, aparejos y fornituras». ${ }^{118}$

Poco duró, sin embargo, la alegría a los navieros. El 10 de octubre de 1583, el Consulado de cargadores a Indias escribe al rey participándole de la necesidad de volver a moderar los fletes, a consecuencia del excesivo precio que han alcanzado en la flota que se apresta para Tierra Firme. Si en las flotas de años precedentes el importe medio de los fletes ronda los 25 ducados por tonelada y 4 de averías, ahora se ha alcanzado la cantidad de 39 ducados y 9 de averías por cada tonelada, es decir, un precio total de 48 ducados. ${ }^{119}$ Era cierto este dato; Benito Luis, escribano público de Sevilla, da fe que el día 6 de octubre, Juan de Uribe Apallúa, señor de la nao El Espíritu Santo, fletó a Juan Alonso Medina para que cargase en su nao 300 botijas peruleras llenas de vino, al precio de 39 ducados de flete y 9 de averías; y a Francisco de Arozas para que pudiese cargar 300 botijas peruleras de vino y 160 arrobas de aceite por la misma cantidad de flete y averías. ${ }^{120}$

El Consejo de Indias, que el 15 de octubre ha consultado al rey con parecer favorable a una moderación de los fletes, ${ }^{121}$ especifica con más detalle cómo ha de usarse la cédula de tasa de fletes, tras haber leído un memorial de la Universidad de mareantes:

\footnotetext{
117 Ibid.

118 Antúnez y Acevedo (1797), p. 172.

119 AGI, Indiferente, leg. 740, N.191a, carta del Consulado de Sevilla al rey, Sevilla, 10 de octubre de 1583 .

120 AGI, Indiferente, leg. 740, N.191b, testimonio del escribano Benito Luis, Sevilla, 11 de octubre de 1583.

121 AGI, Indiferente, leg. 740, N.191, consulta del Consejo de Indias al rey, Madrid, 15 de octubre de 1583.
} 
[...] y en cuanto a la tasa de los fletes, aunque en las últimas ordenanzas que se hicieron [...] se mandó no se tasasen de oficio ni a pedimento de parte sin particular y expresa orden de Vuestra Majestad, visto el exceso que ahora ha habido en los dichos fletes, consultando a Vuestra Majestad se mandó se tasasen con comunicación del Duque de Medina, y atento a lo que ahora refieren [los señores de naos], ha parecido que se dé cédula para que siendo necesario hagan la dicha tasación, y haciéndolo tengan consideración al tiempo y carestía de las cosas y el nuevo gasto y costas que se les ha obligado por las dichas ordenanzas, de manera que con justicia se satisfaga a la pretensión de ambas Universidades y sin que por ninguna vía sea impedimento al breve despacho y salida de la flota, y así va hecha en esta conformidad [...]. ${ }^{122}$

No hemos encontrado ningún rastro documental sobre si finalmente se puso en marcha o no una tasa concreta para los fletes de la flota de Tierra Firme de 1583. Tasa que sí se llevó a efecto once años después, en 1594. A la vista de los precios que iban adquiriendo los fletes, se determinó limitarlos a un máximo de 39 ducados de flete y 12 de avería por tonelada, así de pipería como de ropa. ${ }^{123}$ Resulta significativo subrayar cómo entre las tasas de 1572 y la de 1594 los fletes pasaron de 29-31 ducados (según se trate de pipas o ropa) a 39 (sin distinción de la mercancía), y las averías de 4 a 12 ducados por tonelada.

Hasta 1607 no se vuelve a hablar de tasas de fletes, y aun así no son sino rumores que enseguida ponen en guardia a la Universidad de Mareantes, pero que no pasan de ahí. ${ }^{124}$ Habrá que esperar a 1615 para que nuevamente la tasación de los fletes se convierta en tema de preocupación en la carrera de Indias. Los miembros del Consulado de México solicitaron «que se pusiese punto fijo en los fletes que hubiesen de pagar los frutos que de él [Nueva España] pasaban a España». ${ }^{125}$ A lo que se contestó que

122 AGI, Indiferente, leg. 740, N.198, consulta del Consejo de Indias al rey, Madrid, 15 de octubre de 1583.

123 AGI, Indiferente, leg. 1866, consulta del Consejo de Indias al rey, Madrid, 21 de marzo de 1594.

124 Actas de la Universidad de Mareantes (1972) pp. 98-99, acta de 28 de marzo de 1607.

125 Veitia Linaje (1672), Libro II, Capítulo XVI, 2. 
se estilaba que no hubiese tasa de fletes, con que se concertaban los cargadores con los maestres según la falta o sobra de buques, o de carga, y que así parecía conveniente que hubiese la misma libertad en las Indias, concertándose como pudiesen, pues por los registros constaba que aun por lo pasado se obligaban unos a pagar más y otros menos, con que debía correr para la venida lo mismo que para la ida, mayormente cuando en todo lo posible importaba favorecer a los dueños de naos, que tan acabados estaban. ${ }^{126}$

Por esta vez, aquellos que en tantas ocasiones tasaron los fletes, no obstante las palabras de Veitia, dieron prioridad a la defensa de los intereses de los navieros frente a un determinado grupo de mercaderes. También parece ponerse de manifiesto una tácita jerarquía entre los colectivos participantes en el comercio indiano; si los deseos y peticiones del Consulado de Sevilla están, a la hora de ser atendidos, claramente por encima de los de los mareantes, resulta bastante probable que los problemas de éstos se estimen, a los ojos de las autoridades metropolitanas, como prioritarios frente a los de los comerciantes novohispanos.

A mediados del siglo XVII, y hasta el tiempo en que escribe Veitia Linaje (1672), los fletes han vuelto a tasarse en cantidad de 44 ducados de plata por tonelada, más 14 de averías. ${ }^{127}$ Algunos años después, la Recopilación de Leyes de Indias de 1680 dispone la libertad completa de flete, y toma como punto de referencia la cédula de 14 de diciembre de $1615 .{ }^{128}$

El conflicto entre mercaderes y navieros por mor de la tasación de fletes nos ofrece varias enseñanzas. Cuando el Estado abandona su papel de árbitro imparcial entre los actores privados se inicia la verdadera injusticia: unos son los beneficiados, mientras que el perjuicio queda para los demás. El Estado, en vez de fomentar el acuerdo entre las partes, azuza el enfrentamiento. En este caso, el Consulado es la institución favorecida, y la causa tiene menos que ver con su actividad comercial en la carrera de Indias

\footnotetext{
126 Ibid.

127 Ibid., lib. II, cap. XVI, 3.

128 Recopilación de Leyes de Indias, lib. IX, tít. XXXI, ley 6.
} 
que con el apoyo financiero que otorga a la Corona mediante suculentos «donativos». Entre cargadores y mareantes la elección está clara: los cargadores. Pero no siempre será así, pues el rey necesita barcos para sus armadas, y cuando esta necesidad se hace perentoria, entonces los favorecidos son los mareantes. Si aceptamos el individualismo metodológico, hemos de reconocer que cada uno de estos individuos juega a lo suyo: también el rey.

Por otro lado, los argumentos económicos que manejan cargadores y mareantes son ingenuos, primitivos, de sentido común; nos hablan tanto sobre sus visiones de la economía como acerca de sus inexactitudes teóricas. Inconscientemente manejan la teoría de imputación de costes y no parecen comprender cómo se establecen en realidad los precios. De ahí el valor de teóricos, ma non troppo, como Luis Saravia de la Calle, quien en su Instrucción de mercaderes, de 1544, lo deja claro: «los que miden el justo precio de la cosa según el trabajo, costas y peligros del que trata o hace la mercadería yerran mucho; porque el justo precio nace de la abundancia o falta de mercaderías, de mercaderes y de dineros, y no de las costas, trabajos y peligros»; ${ }^{129}$ o como dice Huerta de Soto, «en todo caso, son los costes los que tienen a seguir a los precios y no al revés». ${ }^{130}$ Una cosa es ser un actor económico, todo lo perspicaz que se quiera, y otra muy distinta ejercer como teórico de la economía.

\section{REFERENCIAS BIBLIOGRÁFICAS}

Actas de la Universidad de Mareantes (1972), estudio preliminar de Luís Navarro García y trascripción de M. ${ }^{a}$ del Carmen Borrego Pla, Sevilla, Diputación Provincial de Sevilla.

AntúNeZ y ACEVEDO, R. (1797): Memorias históricas sobre la legislación y gobierno de los españoles con sus colonias en las Indias occidentales, Madrid, Instituto de Estudios Fiscales, 1981.

Bennassar, B. (1983): La España del Siglo de Oro, Barcelona, Editorial Crítica, 1990.

\footnotetext{
129 Citado por Huerta de Soto (2000), p. 54.

130 Ibid.
} 
Bernal Rodríguez, M.A. (1993): La financiación de la Carrera de Indias (1492-1824). Dinero y comercio en el comercio colonial español con América, Madrid, Fundación El Monte.

BÖHM-BAWERK, E. vON: «La ley básica de determinación del precio», Jesús Huerta de Soto (compilador), Lecturas de Economía Politica. Volumen I, Madrid, Unión Editorial, 1986.

CANO, T. (1611): Arte para fabricar y aparejar naos, edición de Enrique Marco Dorta, La Laguna, Instituto de Estudios Canarios, 1964.

CARANDE, R. (1943): Carlos V y sus banqueros, Barcelona, Editorial Crítica, 1990, vol. I.

Céspedes del Castillo, G. (1945): La avería en el comercio de Indias, Sevilla, Escuela de Estudios Hispano-Americanos.

Chaunu, P. y H. (1955-1960): Seville et l'Atlantique (1504-1650), París, Librairie Armand Colin, vols. III, VIII 2,1 y VIII 2,2 .

ElLiotT, J.H. (1982): «Introspección colectiva y decadencia en España a principios del siglo XVII», idem (editor), Poder y sociedad en la España de los Austrias, Barcelona, Editorial Crítica, 1982.

EnCINAS, D. DE (1596): Cedulario indiano, Madrid, Ediciones Cultura Hispánica, 1946.

Fernández-Guerra Fernández, P. (1991): El fletamento en el derecho naval mercantil castellano, Oviedo, Universidad de Oviedo.

- (1993), «Asientos y fletamentos de naves (1661)», Revista de Historia Naval, Madrid, año IX, n. 40 , pp. 59-68.

García-Baquero GonzÁlez, A. (1998): «La Carrera de Indias en la segunda mitad del siglo XVI: el efecto especular de la nueva situación americana», Congreso Internacional Las Sociedades Ibéricas y el Mar a finales del siglo XVI, Madrid, Comisaría General de España en la Expo de Lisboa'98, tomo IV, pp. 335-357.

GARCÍA FuENTES, L. (1979): «En torno a la reactivación del comercio indiano en tiempos de Carlos II», Anuario de Estudios Americanos, Sevilla, tomo XXXVI, pp. 251-286.

- (1980), El comercio español con América, 1650-1700, Sevilla, Escuela de Estudios Hispano-Americanos - Diputación de Sevilla. 
GARCíA SANZ, A. (1978): «Fletamentos catalanes medievales», Historia, Instituciones, Documentos, Sevilla, Universidad de Sevilla, núm. 5, pp. 237-256.

HARING, C.H. (1918): Comercio y navegación entre España y las Indias en la época de los Habsburgos, México, Fondo de Cultura Económica, 1979.

Hevia Bolaños, J. DE (1617): Labyrintho del Comercio terrestre y naval donde breve y compendiosamente trata de la Mercancía y Contratación de tierra y mar, provechoso para Mercaderes, Negociadores, Navegantes, y sus Consulados, Ministros de los Juicios, profesores de Derecho, y otras personas, Lima.

Huerta de Soto, J. (2000): La Escuela Austriaca. Mercado y creatividad empresarial, Madrid, Editorial Síntesis.

IGLESIAS RODRÍGUEZ, J.J. (1994): «Notas sobre los fletamentos sevillanos (siglos XV-XVI)», Tra Siviglia e Genova: notacio, documento e commercio nell'età colombiana, Milán, Giuffrè Editore, pp. 437-458.

KIRZNER, I. (1973): Competencia y función empresarial, Madrid, Unión Editorial, 1975. Segunda edición, 1998.

Lobo Cabrera, M. (1993): El comercio del vino entre Gran Canaria y las Indias en el siglo XVI, Las Palmas de Gran Canaria, Cabildo Insular de Gran Canaria.

LuQue TAlaVÁN, M. (1998): «La avería en el tráfico marítimomercantil: notas para su estudio (siglos XVI-XVIII)», Revista Complutense de Historia de América, Madrid, núm. 24, pp. 113-145.

MARTíNEZ GiJóN, J. (1983): «La práctica del fletamento de mercancías con las Indias (siglo XVI)», Historia, Instituciones, Documentos, Sevilla, núm. 10, pp. 119-156.

- (1987), El Fletamento en el Derecho Indiano de la Recopilación de 1680», Historia, Instituciones, Documentos, Sevilla, núm. 14, pp. 51-74.

Mises, L. von (1944 y 1962): Burocracia [Gestión empresarial frente a gestión burocrática], Madrid, Unión Editorial, 2005.

Oliva Melgar, J.M. (2004): El monopolio de Indias en el siglo XVII y la economía andaluza. La oportunidad que nunca existió. (Lección inaugural. Curso académico 2004-2005), Huelva, Universidad de Huelva. 
Pirenne, H. (1933): Historia económica y social de la Edad Media, México, Fondo de Cultura Económica, 1970.

Recopilación de Leyes de los Reinos de las Indias (1680), Madrid, Ediciones Cultura Hispánica, 1973.

Roll, E. (1934): Historia de las doctrinas económicas, México, Fondo de Cultura Económica, 1974.

Rubio, J. (1944): «La doctrina del fletamento en Hevia Bolaños», Anuario de Historia del Derecho Español, Madrid, tomo XV (1944), pp. 571-588.

- (1954), El fletamento en el Derecho español, Madrid, Revista de Derecho Privado.

RoJAS VACA, M.D. (1996): El documento marítimo-mercantil en Cádiz (1550-1600). Diplomática notarial, Cádiz, Universidad de Cádiz.

Serrano Mangas, F. (1992): La crisis de la isla del oro. Ensayo sobre la circulación y política monetaria en La Española (1530-1560), Badajoz, Universidad de Extremadura.

THOMPSON, I.A.A. (1981): Guerra y decadencia. Gobierno y administración en la España de los Austrias, 1560-1620, Barcelona, Editorial Crítica.

VAs Mingo, M.M. Del (1989): «Las cartas de fletamento en la comunicación marítima con América (siglos XVI-XVIII)», Actas de las Primeras Jornadas "Presencia de España en América: aportación gallega», Pazos de Mariñán, 28 de septiembre3 de octubre de 1987, La Coruña, Diputación Provincial de La Coruña, pp. 37-50.

Veitia Linaje, J. (1672): Norte de la Contratación de las Indias, Madrid, Ministerio de Hacienda, 1981.

VILAR, P. (1956): «El siglo del Quijote», idem, Crecimiento y desarrollo. Economía e historia: reflexiones sobre el caso español, Barcelona, Planeta-Agostini, 1993, pp. 332-346.

ZuMALACÁRREGUI, L. (1945): «Contribución al estudio de la avería en el siglo XVI y principios del siglo XVII», Anales de Economía, Madrid, vol. IV, n.. 16, pp. 1-42. 